This report was prepared as an account of work sponsored by an agency of the United States Government. Neither the United States Government nor any agency thereof, nor any of their employees, makes any warranty, express or implied, or assumes any legal liability or responsibility for the accuracy, completeness, or usefulness of any information, apparatus, product, or process disclosed, or represents that its use would not infringe privately owned rights. Reference herein to any specific commercial product, process, or service by trade name, trademark, manufacturer, or otherwise does not necessarily constitute or imply its endorsement, recommendation, or favoring by the United States Government or any agency thereof. The views and opinions of authors expressed herein do not necessarily state or reflect those of the United States Government or any agency thereof.

\title{
Greater-Than-Class C Low-Level Radioactive Waste Transportation Strategy Report and Institutional Plan
}

\author{
R. C. Schmitt \\ M. J. Tyacke
}

Published January 1995

\section{Idaho National Engineering Laboratory Lockheed Idaho Technologies Company Idaho Falls, Idaho 83415}

Prepared for the

U.S. Department of Energy

Assistant Secretary for Environmental Management

Under DOE Idaho Operations Office

Contract DE-AC07-94ID13223 



\section{DISCLAIMER}

Portions of this document may be illegible in electronic image products. Images are produced from the best available original document. 


\section{ABSTRACT}

This document contains two parts. Part I, Greater-Than-Class-C Low-Level Radioactive Waste Transportation Strategy, addresses the requirements, responsibilities, and strategy to transport and receive these wastes. The strategy covers (a) transportation packaging, which includes shipping casks and waste containers; (b) transportation operations relating to the five facilities involved in transportation, i.e., waste originator, interim storage, dedicated storage, treatment, and disposal; (c) system safety and risk analysis; (d) routes; (e) emergency preparedness and response; and (f) safeguards and security. A summary of strategic actions is provided at the conclusion of Part I.

Part II, Institutional Plan for Greater-Than-Class C Low-Level Radioactive Waste Packaging and Transportation, addresses the assumptions, requirements, and institutional plan elements and actions. As documented in the Strategy and Institutional Plan, the most challenging issues facing the GTCC LLW Program shipping campaign are institutional issues closely related to the strategy. How the Program addresses those issues and demonstrates to the states, local governments, and private citizens that the shipments can and will be made safely will strongly affect the success or failure of the campaign. 



\section{CONTENTS}

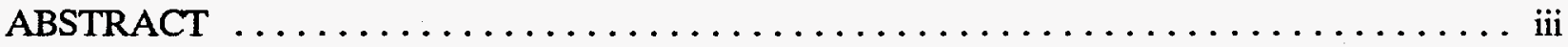

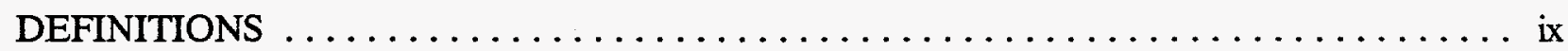

\section{Part I}

\section{Greater-Than-Class-C Low-Level Radioactive Waste Transportation Strategy}

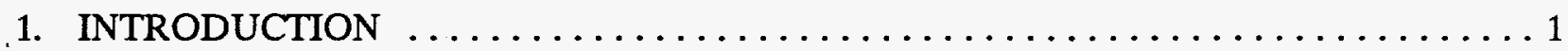

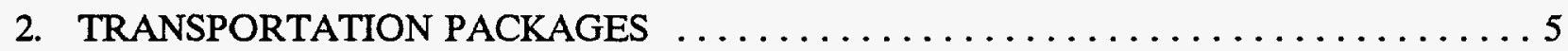





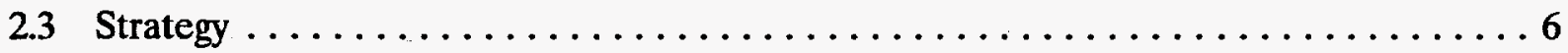

3. TRANSPORTATION OPERATIONS $\ldots \ldots \ldots \ldots \ldots \ldots \ldots \ldots \ldots \ldots \ldots$

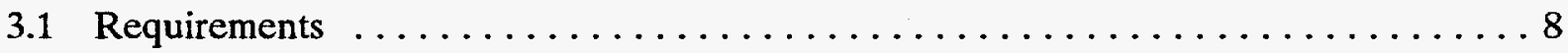

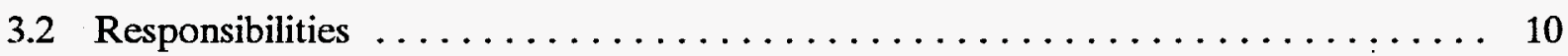

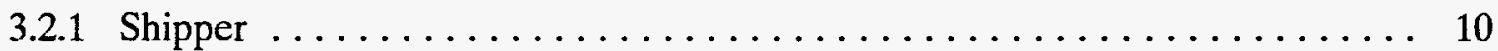

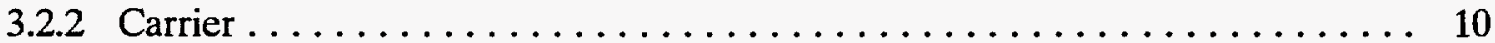

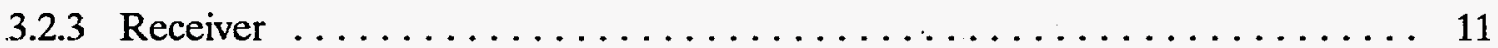

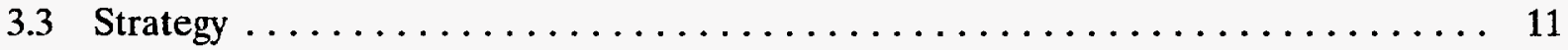

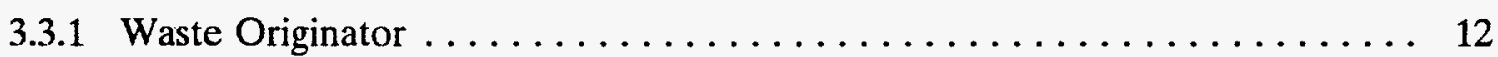

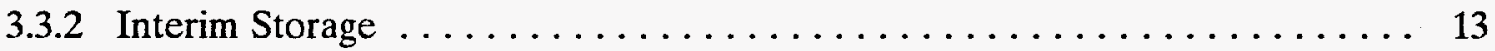

3.3 .3 Dedicated Storage $\ldots \ldots \ldots \ldots \ldots \ldots \ldots \ldots \ldots \ldots \ldots \ldots \ldots \ldots \ldots \ldots \ldots \ldots$

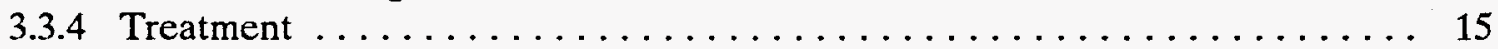

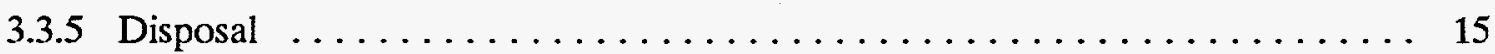

4. SYSTEM SAFETY AND RISK ANALYSIS $\ldots \ldots \ldots \ldots \ldots \ldots \ldots \ldots \ldots \ldots \ldots \ldots$

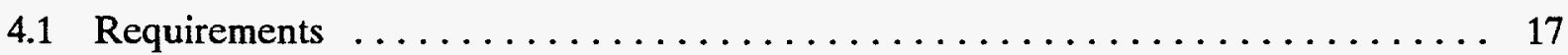

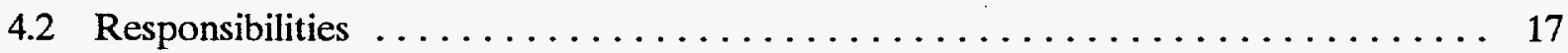

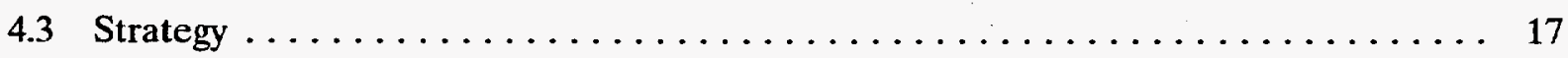




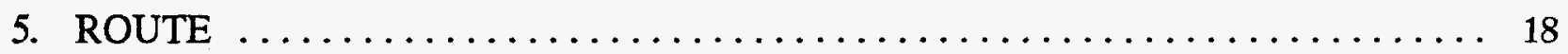

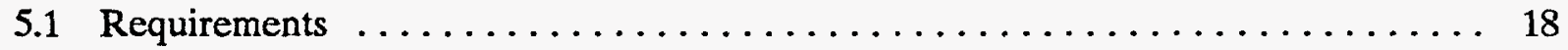

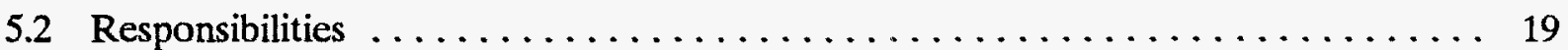

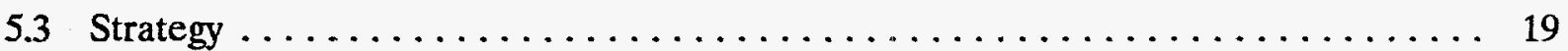

6. EMERGENCY PREPAREDNESS AND RESPONSE $\ldots \ldots \ldots \ldots \ldots \ldots \ldots \ldots \ldots$.

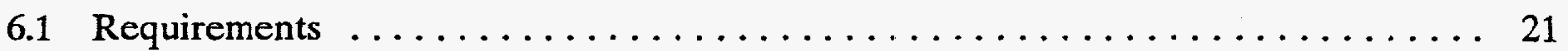

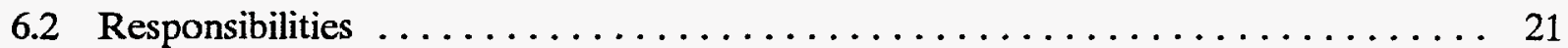

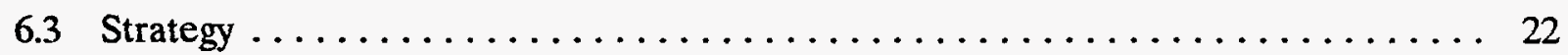

7. SAFEGUARDS AND SECURITY $\ldots \ldots \ldots \ldots \ldots \ldots \ldots \ldots \ldots \ldots \ldots \ldots$

7.1 Requirements $\ldots \ldots \ldots \ldots \ldots \ldots \ldots \ldots \ldots \ldots \ldots \ldots \ldots \ldots \ldots \ldots$

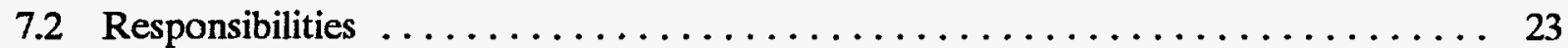

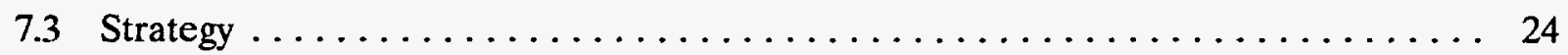

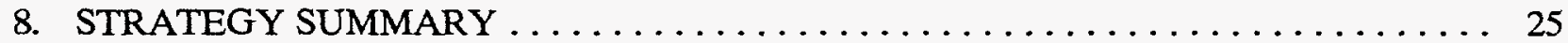

9. REFERENCES .............................. 28

\section{FIGURES}

1. Possible shipper and receiver options for (a) originator facility, (b) interim storage facility, (c) dedicated storage facility, (d) treatment facility, and (e) disposal facility $\ldots \ldots \ldots \ldots$

2. Possible shipper and receiver options for the waste originator facilities. $\ldots \ldots \ldots \ldots 12$

3. Possible shipper and receiver options for interim storage $\ldots \ldots \ldots \ldots \ldots \ldots \ldots \ldots$

4. Possible shipper and receiver options for a dedicated storage facility. . . . . . . . 14

5. Possible shipper and receiver options for a treatment facility. . . . . . . . . 16

6. Possible shipper and receiver options for a disposal facility. $\ldots \ldots \ldots \ldots \ldots$ 


\section{TABLES}

1. Potential generator or sources of GTCC LLW and associated radionuclides. ....... 2

2. Quantities of nuclear materials above which are reportable to the DOE.

(DOE Order 5633.3, "Control and Accountability of Nuclear Materials,"

February 3, 1988)

\section{Part II}

\section{Institutional Plan for Greater-Than-Class C Low-Level Radioactive Waste Packaging and Transportation}

1. INTRODUCTION $\ldots \ldots \ldots \ldots \ldots \ldots \ldots \ldots \ldots \ldots \ldots \ldots \ldots \ldots \ldots \ldots$



3. REQUIREMENTS $\ldots \ldots \ldots \ldots \ldots \ldots \ldots \ldots \ldots \ldots \ldots \ldots \ldots \ldots \ldots \ldots \ldots$

4. INSTITUTIONAL PLAN ELEMENTS AND ACTIONS $\ldots \ldots \ldots \ldots \ldots \ldots \ldots \ldots$

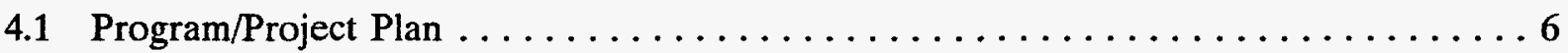

4.2 Public Information Planning and Coordination $\ldots \ldots \ldots \ldots \ldots \ldots \ldots \ldots$

4.3 Environmental Compliance Documentation $\ldots \ldots \ldots \ldots \ldots \ldots \ldots \ldots \ldots$

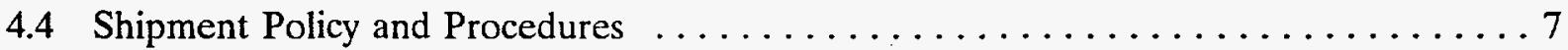

4.5 State, Local, and Tribal Interaction $\ldots \ldots \ldots \ldots \ldots \ldots \ldots \ldots \ldots \ldots \ldots \ldots \ldots \ldots$

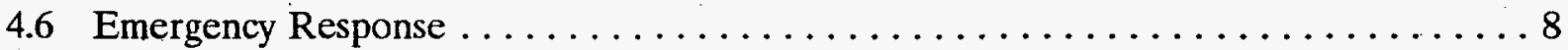

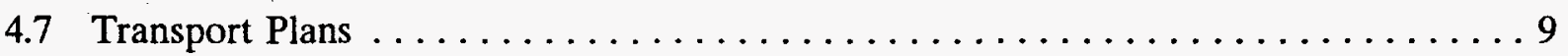

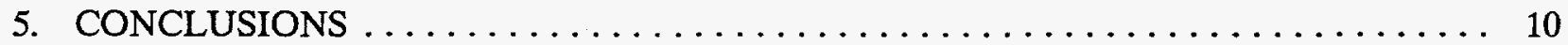

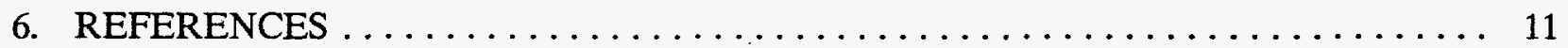

\section{TABLE}

1. Summary of Institutional Plan action items $\ldots \ldots \ldots \ldots \ldots \ldots \ldots \ldots \ldots \ldots \ldots$ 


\section{DEFINITIONS}

$\boldsymbol{A}_{\boldsymbol{1}}$. The maximum activity of special form radioactive material permitted in a Type A package. (49 CFR 173.403)

$A_{2}$ The maximum activity of radioactive material, other than special form or low specific activity radioactive material, permitted in a Type A package. These values are either listed in $\$ 173.435$ or may be derived in accordance with the procedure prescribed in $\$ 173.433$. (49 CFR 173.403)

Carrier. The common carrier having physical custody of the radioactive and/or fissile package during transport.

Disposal facility. A facility that will provide permanent isolation of GTCC LLW. The facility will be licensed by the Nuclear Regulatory Commission (NRC).

Fussile material. Any material consisting of or containing one or more fissile radionuclides. Fissile radionuclides are plutonium-238, plutonium-239, plutonium-241, uranium-233, and uranium-235. Neither natural nor depleted uranium is fissile material. Fissile material is classified according to the controls needed to provide nuclear criticality safety during transportation, as provided in \$173.455. Certain exclusions are provided in \$173.453 (49 CFR 173.403). DOE Order 5480.3 identifies two additional fissile radionuclides, neptunium-237 and curium-244.

Interim storage. A storage capability established by the Department of Energy (DOE) to accept limited quantities of GTCC LLW when the licensing agency certifies that the waste generator is unable to safely store it and no other alternative exists.

Packaging. The assembly of components necessary to ensure compliance with the packaging requirements of 10 CFR 71 (49 CFR 173, Subpart I). It may consist of one or more waste receptacles, absorbent materials, spacing structures, thermal insulation, radiation shielding, and devices for cooling or absorbing mechanical shock. The vehicle, tie-down system, and auxiliary equipment may sometimes be designated as part of the packaging. (10 CFR 71.4 and 49 CFR 173.403)

Preferred route or preferred highway. A highway for shipment of highway route-controlled quantities of radioactive materials so designated by a state routing agency, and any interstate system highway for which an alternate highway has not been designated by such state agency as provided by $\$ 177.825(\mathrm{~b})$. (49 CFR 171.8)

Receiver. The person and/or facility responsible for receiving the radioactive shipment. The receiver must be authorized to receive the specific material being shipped.

Safety Analysis Report for Packaging (SARP). A document that provides a comprehensive technical evaluation and review of the design, testing, operational procedures, maintenance procedure, and quality assurance program to demonstrate compliance with the NRC regulatory safety standards or equivalent standards established by DOE for approving packaging and issuing certificates of compliance. (DOE 1540.2) 
Shipper. The person/facility preparing the package for shipment. The shipper is responsible for certifying that the shipment is in compliance with applicable regulations prior to being shipped.

Shipping package. Package means the packaging together with its radioactive contents as presented for transport. (10 CFR 71.4)

Special form. Radioactive material that (a) must be a single solid piece or contained in a sealed capsule that can be opened only by destroying the capsule, (b) have at least one dimension not less than 5 millimeters ( 0.197 inch), and (c) must meet applicable test requirements as defined in 49 CFR 173.469. Special form encapsulations designed in accordance with the requirements of 49 CFR $173.389(\mathrm{~g})$ in effect on June 30,1983 , and constructed prior to July 1,1985 , may continue to be used. [DOE 1540.2 and 49 CFR 173.403(z)]

Type A package. Contents limited to Type A quantity [does not exceed $A_{1}$ (special form) or $A_{2}$ (regular form) radioactive material]. Packaging designed to retain the integrity of containment and shielding required by 49 CFR 173 , Subpart I, under normal condition of transport as demonstrated by tests set forth in $\$ 173.465$ and $\$ 173.466$, as appropriate. (10 CFR 71.4 and 49 CFR 173.403)

Type B package. Contains radioactive material greater than Type A quantity. Packaging designed to retain the integrity of containment and shielding required by 49 CFR 173 , Subpart I, when subjected to the normal conditions of transport and to hypothetical accidents as set forth in 10 CFR Part 71. (10 CFR 71.4 and 49 CFR 173.403)

Waste container. General term for receptacle (i.e., drum, box, can) used to contain radioactive waste. Some waste containers are designated for specific packages, others are used for storage and may not be acceptable to contain radioactive waste during transport. (Not a regulatory definition)

Waste originator facility. The facility where the waste originates, which could vary from a commercial nuclear power plant or medical facility, to the garage or storage shed of a private person.

Waste package. Waste form and any containers, shielding, packing, and other absorbent materials immediately surrounding an individual waste container. (10 CFR 60.2; there is no similar definition for LLW defined in 10 CFR 61) 


\section{Part I}

\section{Greater-Than-Class-C Low-Level Radioactive Waste Transportation Strategy}

\section{INTRODUCTION}

Over 2.5 million shipments of radioactive material are made each year throughout the United States. ${ }^{1}$ The shipments vary from small amounts of radioactive material (e.g., samples) to highly radioactive spent nuclear fuel. These shipments are being made safely with minimal risk to the public and environment. Shipments of radioactive material have been involved in accidents; however, there has never been a death or serious injury resulting from the radioactive properties of the material during an accident. The primary reason for this outstanding safety record is the stringent operational and packaging regulations associated with shipping of radioactive materials.

The federal government is responsible for disposal of greater-than-Class $\mathrm{C}$ low-level radioactive waste (GTCC LLW) by virtue of Section 3(b) of the Low-Level Radioactive Wasty Policy Amendments Act of 1985, Public Law 99-240. GTCC LLW is radioactive waste generated by licensees of the Nuclear Regulatory Commission (NRC) or Agreement States that exceed the Class C limits identified in 10 CFR 61 for disposal of commercial low-level radioactive waste sites. The Department of Energy (DOE) was tasked by the U.S. Congress to be responsible for management and disposal of GTCC LLW. The National GTCC LLW Program was established by DOE to plan for and carry out this task. Transportation is one of the major activities in the GTCC LLW Program.

Part I of this report presents a strategy for transporting GTCC LLW. There are four major waste streams that produce GTCC LLW: activated metals, processed waste, dry contaminated solids, and sealed sources. Report DOE/LLW-114² categorizes GTCC LLW into the following types:

- Nuclear utility waste

- From operations

- From decommissioning

- $\quad$ Sealed Sources

- DOE-held potential GTCC LLW

- Other generators' waste.

Table 1 identifies the waste generators or sources of GTCC LLW, the four major waste streams, and the radionuclides associated with the waste. 
Table 1. Potential generator or sources of GTCC LLW and associated radionuclides.

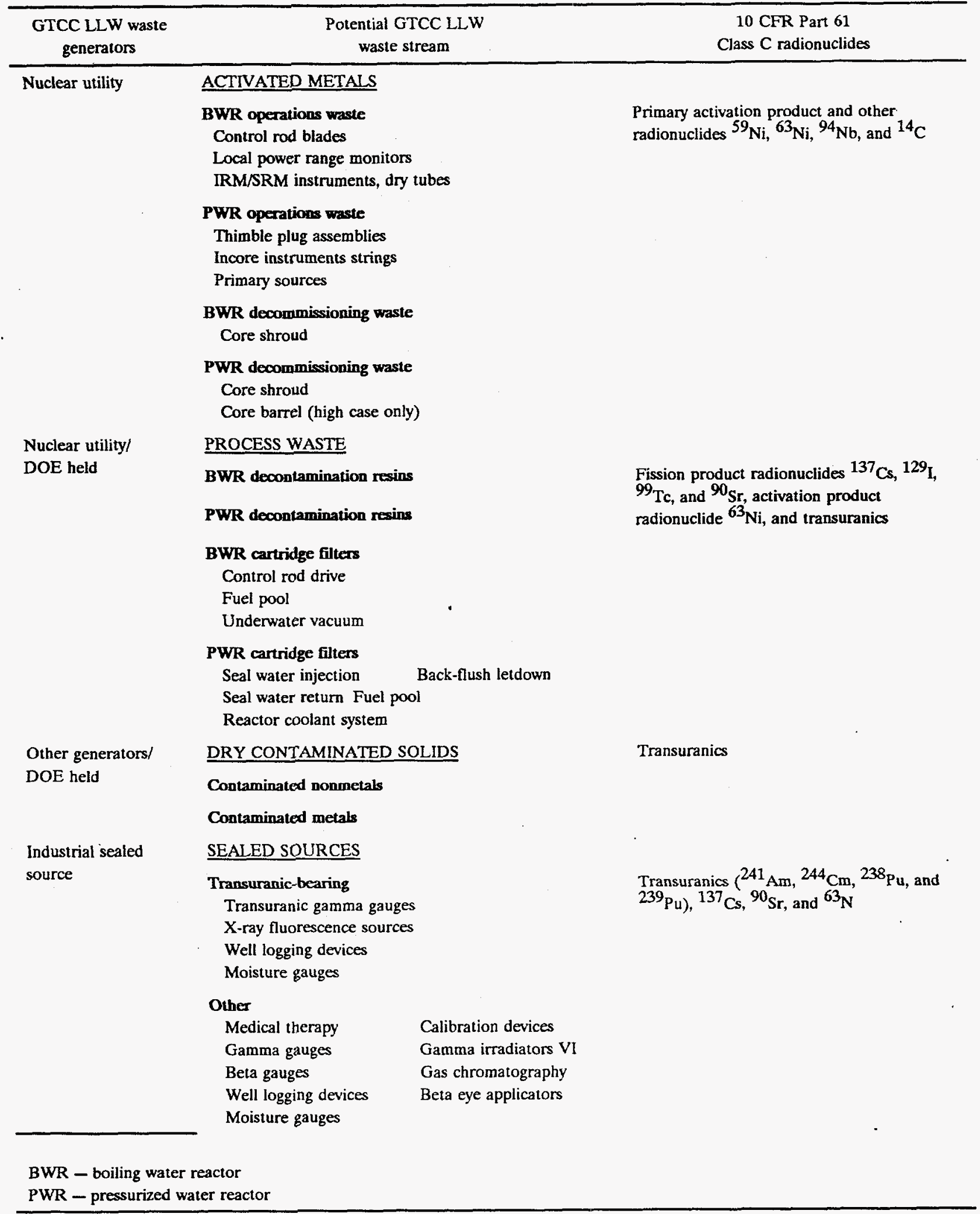


Five locations may be involved in the GTCC LLW shipping campaign:

- Waste originator

- Interim storage (availability to be determined)

- Dedicated storage facility (scheduled to be available by 1999)

- Treatment facility (availability to be determined)

- Disposal facility (scheduled to be available by 2010).

This report identifies activities and responsibilities for making shipments between the above locations efficiently and in compliance with all regulations and requirements. Since the details of the Program have not been established, the strategy includes options for various shipping scenarios. The responsibilities for transporting the waste are divided among three major participants: shipper, carrier, and receiver. Figure 1 shows the above locations and the possible shipper/receiver scenarios for each location. The regulations and requirements for shipping GTCC LLW are discussed in detail in a separate report, DOE/LLW-178, Greater-Than-Class C Low-Level Radioactive Waste Transportation Regulation and Requirements Study. ${ }^{3}$

There have been a number of shipping campaigns conducted by DOE. An analysis was prepared by Battelle Memorial Institute of spent nuclear fuel shipping campaigns between 1983 and 1987. Battelle issued report BMI/OTSP-03, Analysis of Institutional Issues and Lessons Learned from Recent Spent Fuel Shipping Campaigns (1983-1987). ${ }^{4}$ Even though requirements for spent fuel shipments and GTCC LLW shipments differ, there are also similarities. Many of the lessons learned from those campaigns have been incorporated into the strategy and institutional planning of this report. 


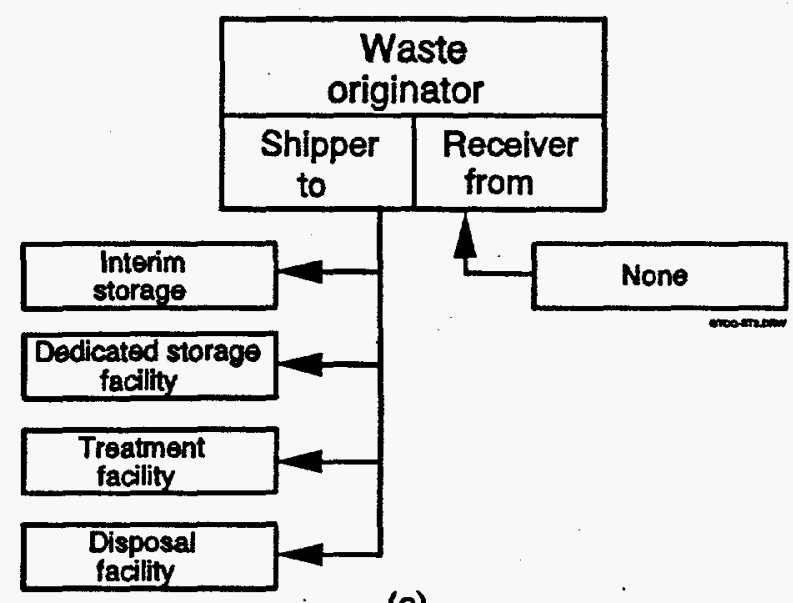

(a)

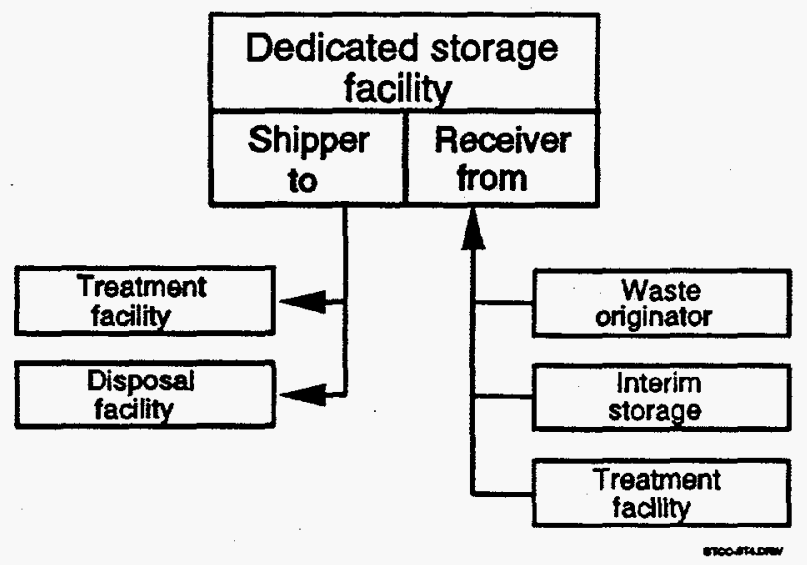

(c)

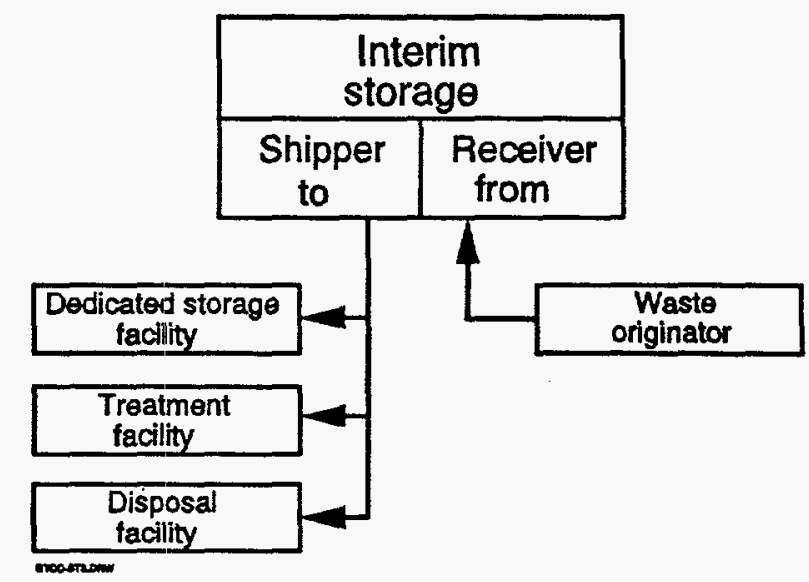

(b)

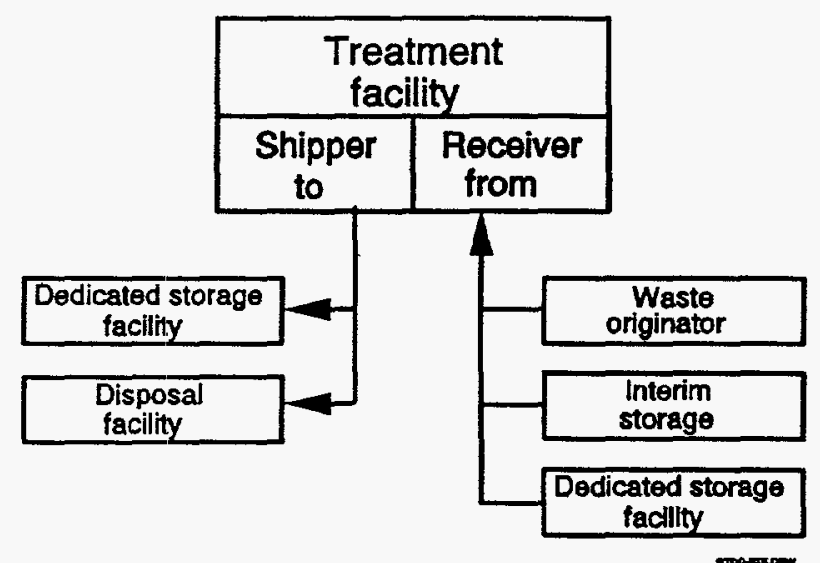

(d)

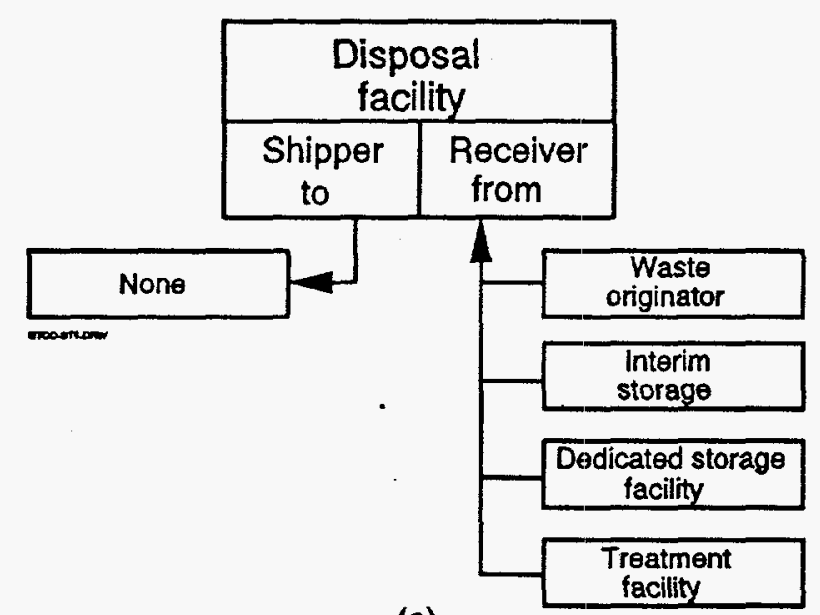

(e)

Figure 1. Possible shipper and receiver options for (a) originator facility, (b) interim storage facility, (c) dedicated storage facility, (d) treatment facility, and (e) disposal facility. 


\section{TRANSPORTATION PACKAGES}

This section presents a strategy for acquiring the necessary and optimum types of transportation packages needed for shipping GTCC LLW. Transportation packages include both the shipping cask and the waste container. Since GTCC LLW varies greatly in size, shape, and activity levels, the cask and waste containers could vary in size from small (to accommodate a single sealed radioactive source) to very large-capacity casks/canisters of a type typically used to transport or dry-store highly radioactive spent fuel. In some cases, the waste containers may serve directly as transportation packages, as is often the case for sealed sources, while in other cases, the containers must be placed into a shipping cask. Report DOE/LLW-184, Greater-ThanClass C Low-Level Radioactive Waste Shipping Package/Container Identification and Requirements $S t u d y,{ }^{5}$ identifies a wide variety of shipping packaging and waste containers and discusses in detail shipping packaging and waste containers, and the requirements that could apply to the campaign.

Several factors must be considered when determining shipping packaging and waste containers.

- $\quad$ The packaging type must be appropriate (i.e., Type A, Type B, fissile, and/or double containment depends on the type and quantity of radionuclides in the waste)

- The appropriate shielding for the packaging depends on the activity levels of the waste

- The packaging and waste container handling capabilities and interface at the shipping and receiving facilities must be considered before packaging and waste containers can be selected

- A careful modal study involves tradeoffs in use of rail versus truck transporters and overweight versus regular weight.

\subsection{Requirements}

The packaging standards and limits for contents of radioactive materials are found in Department of Transportation regulations under 49 CFR 173. The Department defines packaging requirements based on the radioactivity level of the contents. $A_{1}$ means the maximum activity of special form material permitted in a Type $A$ package. $A_{2}$ means the maximum activity of radioactive material other than special form or low specific activity radioactive material permitted in a Type A package. Special form is radioactive material that has been demonstrated to satisfy specified conditions that limit material mobility. Quantities above $A_{1}$ or $A_{2}$ must be packaged in Type B packaging. Significant quantities of GTCC LLW are likely to require Type B packages.

The NRC sets the standards and procedures and certifies packages for fissile materials, including Type B shipping packages. NRC requirements for certification of Type B packages are specified in 10 CFR 71. The Department of Energy also has authority to certify packaging as presented in 49 CFR 173.7 (d). DOE certification requirements identified in DOE Order 1540.2 
and DOE Order 5480.3 require that Type B packaging owned or controlled by DOE or its contractors meet the standards specified in 10 CFR 71 .

Experiences from previous shipping campaigns ${ }^{4}$ show that the public is concerned about the safety of casks, especially casks used in DOE shipments not certified by the NRC. These public concerns could be alleviated if DOE used only NRC-licensed casks for GTCC LLW shipments. If the decision is made to use DOE-certified casks, the program should provide public information and public outreach about the casks regarding equivalent certification processes.

\subsection{Responsibilities}

The shipper is usually responsible for providing the shipping packages and waste containers. For GTCC LLW, it is reasonable to require that the waste originators provide the waste container, shipping packages, and the carrier for shipments to DOE facilities. However, to ensure compatibility with the receiving facilities, DOE and/or its contractor needs to prepare acceptance criteria for waste containers and shipping packages. Without such criteria, the facility will need equipment and procedures, personnel training, and storage capabilities for every shipping configuration offered by the originators, which could be significant.

For shipments from DOE facilities to other DOE facilities, DOE and/or its contractor will be responsible for providing waste containers if the original container does not meet acceptance criteria.

\subsection{Strategy}

Acquiring the necessary and optimum types of shipping packaging and waste containers involve the following activities: (a) clearly defining GTCC LLW (b) developing waste acceptance criteria, (c) preparing a cost benefit analysis for packaging, (d) identifying the interface requirements between the package and facilities, and (e) preparing a modal study. A discussion of these activities follows.

- Defining GTCC LLW-A clear understanding of which radionuclides are present in the waste is needed to determine the appropriate type of packaging, i.e., Type A, Type B, fissile, and/or double containment. Activity levels for these radionuclides are required to determine the appropriate shielding for the packaging.

- Developing waste acceptance criteria-Quantity and sizes of the GTCC LLW materials are needed to determine the number and sizes of the waste containers and shipping packages. However, the facilities' waste acceptance criteria will also strongly influence the number and types of waste containers and shipping packages.

- Interface requirements between the package and facilities-Packaging and waste container handling capabilities and requirements at the shipping and receiving facilities must be identified. Interface requirements between those facilities must be clearly identified before packaging and waste containers can be selected. This involves communication between the waste originator and the program personnel. 
- Modal study-Careful examination of the tradeoffs involved in modal decisions (i.e., railroad versus highway) is required. Railroad shipments allow for the use of larger packages and fewer shipments and potentially improved scheduling controls and cost savings. However, not all facilities are accessible by rail, and most rail routes go through large population areas, which is an institutional concern. Highway transport is accessible to all facilities and, in most cases, have routes that bypass large population areas. However, truck packages are usually smaller than rail packages, which would require more shipments and the shipments would intermingle with the general public on public highways. In determining the size of a package, consideration must be given to the use of overweight trucks. To qualify for federal highway funds, federal laws limit gross vehicle weights to $80,000 \mathrm{lb}$ on interstate highways. A vehicle in excess of this weight must obtain a permit from each state in which it operates. In addition, some local governments and toll authorities can establish weight limits and issue permits that are more restrictive than the state. Permitting procedures vary greatly from state to state. For campaigns that involve a large number of states and bridges or toll authorities, obtaining permits may be a time-consuming task for carriers. Restrictions that apply to overweight vehicles, such as time of day, day of the week, escorts, and inspections can make shipment scheduling difficult. States and local governments may try to use permitting as a means of stopping the shipments through their areas. The use of overweight trucks should be avoided whenever possible.

- Cost benefit analysis for waste containers and shipping packaging-Once the characteristics of the waste, total number of shipments, and packaging requirements have been determined, a cost benefit analysis should be done to determine which option will best meet the Programs' and taxpayers' needs, e.g., buy, lease, or develop new packaging(s) specifically for GTCC LLW. Reference 5 identifies numerous packages available for lease or purchase. 


\section{TRANSPORTATION OPERATIONS}

Transportation operations are divided between shipper, carrier, and receiver. The responsibility and strategy for each of these operations can vary depending on the facility's involvement. The GTCC LLW shipments will be unique in that they will be composed of numerous materials from a wide variety of industries. The waste will be in various shapes, forms, sizes, activity levels, and quantities.

The following sections are written to ensure that the shipping operations are done efficiently and in compliance with the appropriate rules and regulations. Section 3.1 identifies the requirements. Section 3.2 describes the responsibilities of the shipper, carrier, and receiver. Section 3.3 identifies the roles and strategy for the waste originator, interim storage facility, dedicated storage facility, treatment facility, and disposal facility as related to transporting the GTCC LLW.

\subsection{Requirements}

Transportation operations are primarily governed by the federal government (DOT, NRC, DOE, EPA, and OSHA-Occupational Safety and Health Administration) and to some extent state and local governments. These regulations and requirements are identified in Reference 3. The shipper, carrier, and receiver responsibilities are defined by DOT in 49 CFR. DOE orders $1540.1,1540.2$, and 5480.3 require that DOE shipments be made in accordance with DOT regulations.

DOT requires that a shipper properly identify the material; determine the mode of transport; identify any restrictions; prepare shipping papers; certify that the material being shipped is properly classified, described, packaged, marked, and labeled; and is in proper condition for transport according to applicable DOT regulations. Additional requirements include training; making notifications to the receiver, state and local governments, and Native American tribes as required; keeping records; maintaining a 24-hour emergency response telephone number; providing the carrier with written instructions and emergency response procedures, as required; providing the receiver with information pertaining to the waste classification and characterization and special unloading instruction, if needed; and tracking and surveillance, if needed.

The NRC regulations for operating radioactive material shipments are found in 10 CFR 71, Subpart G, Operating Controls and Procedures, \$71.81 through \$71.99.

The shipper is required to offer placards to the carrier unless the shipment is by rail. The shipper puts the placards on transport vehicles.

Transporting hazardous waste requires that (a) EPA Form 8700.22, and when required Form 8700.22a, Hazardous Waste Manifest, be prepared in accordance with 40 CFR 262.20 (see 49 CFR 172.205), and (b) each package and container be marked as required by 49 CFR 172.300. Markings must also comply with EPA requirements described in 40 CFR 262.32. 
The Department of Labor administers OSHA regulations specified in 29 CFR. These regulations ensure to the extent possible that all employees have safe and healthful working conditions, and preserve human resources.

State and local governments and Native American tribes enforce the DOT regulations and impose requirements of their own. Not all state, local, and tribal requirements will stand up in a court of law; however, DOE is committed to comply with applicable state regulations, tribal laws, and local ordinances. ${ }^{6}$ DOE may be directed to enter into consultation and cooperative agreements with transportation corridor states, tribes, and local authorities. It may be necessary to develop some components of the transportation system to meet the special needs of the state and local governments. An example is a possible cooperative agreement in state inspections of the shipments. No requirement exists for states to inspect shipments of GTCC LLW. However, shippers of spent fuel shipping campaigns have identified significant advantages by facilitating state inspections. ${ }^{4}$. The inspections reassured state officials concerned about public health and safety and enhanced good working relations that lead to the acceptance of the shipments. However, multiple state inspections are inefficient and cause delays. Development of multistate agreements on inspection frequency could be cost effective and more efficient. With such an agreement, transportation vehicles, cargo, and personnel qualifications would be inspected only at an agreed-upon frequency. To develop reciprocal agreements between states, there must be similar inspection and enforcement requirements, i.e., a uniform set of inspection standards. The DOE Office of Civil Radioactive Waste Management has a cooperative agreement with the Commercial Vehicle Safety Alliance to develop uniform inspection and enforcement procedures. The GTCC LLW Program may want to obtain those procedures and consider using similar procedures for the GTCC LLW shipping campaign.

Highway-route-controlled quantities of radioactive materials, as defined in 49 CFR 173.403(l), have additional requirements. These requirements include a route plan and special training for the driver as defined by 49 CFR 177.825 . Highway-route-controlled quantities of radioactive materials also have special placarding requirements.

The spill-reporting requirements in 49 CFR 171.15, Immediate Notice of Certain Hazardous Materials Incidents, requires carriers to immediately report to DOT specified incidents during loading, temporary storage, transportation, or unloading. Additional reporting requirements are found in 49 CFR 171.16, Detailed Hazardous Materials Incident Report; 40 CFR 302.6, EPA Special Reporting Requirements for Hazardous Substance Discharges; 40 CFR 355.401, Reporting Requirements for Discharges of Extremely Hazardous Substances; and 40 CFR 355.40.(b)(3), Follow-Up Notice Requirements.

DOE's reporting requirements for occurrences are found in DOE Order 5000.3B. Occurrences are all events that could (a) affect the health and safety of the public, (b) have a serious impact on the intended purpose of DOE facilities, (c) have a noticeable adverse effect on the environment, or (d) endanger the health and safety of workers. This order also establishes a system for determining appropriate corrective action and for ensuring that such action is effectively taken.

The NRC regulations involving receiving operations in radioactive material shipments are found in 10 CFR 71, Subpart G, Operating Controls and Procedures, \$71.81 through \$71.99. This 
subsection identifies, among other things, (a) applicability of operating controls and procedures, (b) opening instructions, (c) records, (d) inspections and tests, (e) reports, and (f) violations.

The receiver must (a) respond to arrival notifications by being ready to process the papers necessary to receive, take title to, and process the material, (b) have personnel ready and trained to physically accept the waste, (c) inspect and confirm that the payload corresponds to the shipping and title records, and (d) provide the shipper and the transporter with all the receipts and releases and other documentation needed to meet all legal, regulatory, and administrative requirements for each.waste shipment.

\subsection{Responsibilities}

The responsibilities for shipping operators are divided between shipper, carrier, and receiver. The following is a discussion of the responsibilities for each party involved with the shipment.

\subsubsection{Shipper}

The shipper for the GTCC LLW Program will be either the waste originator, DOE, or a DOE contractor. As stated previously, the shipper is responsible for preparing the radioactive material for transport and certifying that the shipment meets the regulatory requirements. The shipper will usually be responsible for providing the shipping packaging; however, there are situations, e.g., contractual agreements and/or waste responsibilities, which may result in the carrier or the receiver being responsible for providing the packaging.

\subsubsection{Carrier}

The carrier is usually responsible for providing the transporter and drivers. The carrier is usually contracted by the shipper to transport the material from point of origin to destination. However, there may also be situations such as contractual agreements and/or waste responsibilities that cause the receiver to be responsible for providing a carrier. For the GTCC LLW shipments, the waste originator is responsible for providing a carrier for transporting the waste to the DOE facilities unless there are circumstances (abandoned sources, bankrupt businesses, etc.) that require DOE or its contractor to be responsible for arranging for a carrier.

The carrier responsibilities include (a) inspecting transportation equipment for safety prior to leaving the point of origin, including tiedowns; additional inspections may be made by federal, state, or local competent authorities, if authorized; (b) ensuring the vehicle is properly placarded; (c) ensuring that the routes minimize radiological risk; and (d) training truck drivers or train operators in the operation of their mode of transportation, emergency conditions, and procedures.

To ensure that the truck drivers have pertinent regulations readily available, the carrier should provide the drivers with the American Trucking Association's pocket-size booklet, Federal Motor Carrier Safety Regulations, ${ }^{7}$ which contains 49 CFR 383, 390-397, and 399 regulations. The carriers should also provide the drivers with the latest version of the Emergency Response Guidebook, DOT P 5800.5..$^{8}$ 


\subsubsection{Receiver}

The receiver for the GTCC LLW Program will be DOE, its contractor, or both. It is not anticipated that waste will be returned to the originator, though the program will require a strategy with regard to materials not in compliance with acceptance criteria. Typically, the shipper and the receiver have the responsibility to negotiate receipt of the material in accordance with acceptance criteria, such that the receiver is authorized to receive the specific material being shipped prior to the shipment being made. The disposal facility will be certified by the NRC, but other facilities may not be; it depends on DOE's involvement. An important responsibility of the receiver is to develop the waste acceptance criteria.

\subsection{Strategy}

The GTCC LLW transportation operations strategy must be developed around the transportation activities and the facilities. There are potentially five facilities involved in the shipment of GTCC LLW. Three of those facilities could be responsible for both receiving and shipping. Figure 1 identifies the five possible facilities and the possible shipper and receiver role.

The need for effective shipment planning and close coordination of shipment participants is critical to a successful shipping campaign. Efforts are underway by the GTCC LLW Program to clearly understand GTCC LLW, including who has GTCC LLW materials and where it is located; how much is there; and the composition of the waste (radionuclides, activity levels, size, shape, form, etc.). Once that information is available, a waste acceptance criterion for each facility must be developed. That acceptance criterion must integrate the needs of waste generators, packaging supplier(s), and receiving facility. Without waste acceptance criteria, all of the GTCC LLW may not be receivable, shipping packages may not be available, or the receiver may not be able to receive and handle the waste safely and efficiently. Notwithstanding such acceptable criteria, the program must also establish a strategy for materials that might be received that are nonconforming or not in compliance with acceptance criteria.

Since DOE will be responsible for all of the transportation activities except for those by the waste originator, an important strategy is that top-level planning be done that integrates all phases of transportation. Examples of that type of planning should include (a) shipment tracking in transit and communication between transport vehicle and traffic management, (b) security, (c) emergency notifications, (d) routing, (e) notifications, (f) driver training and qualifications, (g) vehicle maintenance and inspection surveillance by state, local governments and Native American tribes, (h) inspection and recertification of transport packaging, (i) worker hazardous communications and protection, (j) loading and unloading procedures, and $(k)$ a quality assurance plan for transportation and receipt.

Other planning includes (a) waste transportation policies and procedures, (b) hazardous material transportation safety training procedures, (c) detailed operating procedures (DOPs) for loading, unloading, maintenance, and inspections, etc., and (d) records management procedures.

The following sections identify specific roles and possible strategies for each facility. 


\subsubsection{Waste Originator}

As shown in Figure 2, the waste originator will be the shipper and not a receiver. The originator may be required to ship the waste to the interim storage facility, dedicated storage facility, treatment facility, and/or disposal facility. It is not anticipated that the originator will need to receive a shipment; however, if required, DOE should not be responsible for the action.

Thirteen kinds of businesses have been identified as possible generators of GTCC LLW.,9 Those businesses are

- Carbon-14 users

- Nuclear fuel fabricators

- Medical research and development firms

- Nuclear research reactors

- Sealed source distributors and users

- $\quad$ Sealed source manufactures

- Nonmedical academic institutions

- Nonresearch medical institutions

- Analytical laboratories

- Waste services companies

- Manufacturers of devices containing sealed sources.

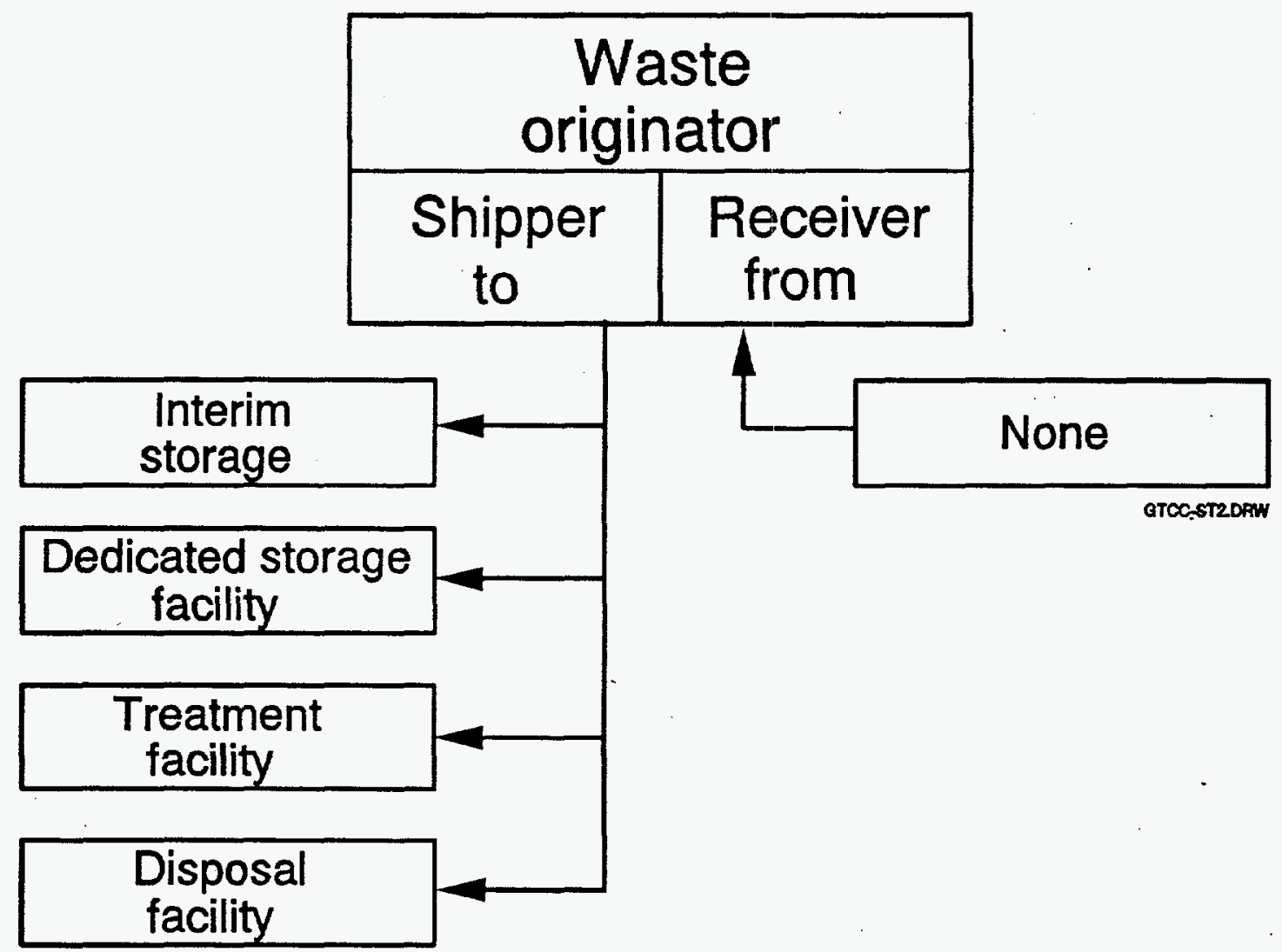

Figure 2. Possible shipper and receiver options for the waste originator facilities. 
The DOE and its contractor should minimize their involvement in preparing and shipping waste from the waste originator to the DOE facilities. Once DOE becomes involved, there is a greater chance that state and local governments and private citizens will become involved. The waste originator should be responsible for preparing the waste for shipment and for providing the waste containers, shipping packages, and the contract with a carrier for shipment to the DOE facilities. However, since the casks and waste containers could very significantly in size and operation handling requirements, waste acceptance criteria should be developed by the DOE facilities as previously discussed. The waste originator should also handle institutional issues (i.e., routes, inspections, notifications). This may need to be a joint responsibility between the waste originator and DOE if the shipments originate in the same general area as shipments by other originators and involve a large number of shipments using the same routes. However, if at all possible DOE should not get involved in these shipments. Hazardous material shipments are made routinely throughout the United States with minimal involvement by state and local governments and private citizens.

DOE and its contractor will need to develop waste acceptance criteria and verify that the originator is satisfying those criteria. DOE will also need to coordinate institutional issues in the areas where DOE facilities are located.

\subsubsection{Interim Storage}

The DOE strategy for interim storage is to accept limited amounts of GTCC LLW for storage prior to dedicated storage, treatment, or disposal being available. Acceptance is restricted to GTCC LLW that presents a significant risk to public health and safety.

As can be seen in Figure 3, interim storage could be a receiver from the waste originator, and a shipper to a dedicated storage facility, treatment facility, and/or a disposal facility. DOE and its contractor will need to develop waste acceptance criteria and verify that the originator is satisfying those criteria and that the originator provides acceptable waste containers and shipping packaging, arranges for the carrier, and performs the functions of the shipper and receiver.

\subsubsection{Dedicated Storage}

The DOE strategy for dedicated storage is to accept GTCC LLW for storage, pending availability of disposal capacity. It is anticipated that dedicated storage will be established by 1999. DOE is currently evaluating the options for providing dedicated storage at one of the existing DOE facilities or developing a new facility. If a new facility is developed, it may be operated by the private sector, which may affect the transportation operations strategy. Should DOE provide a dedicated storage facility, NRC licensing will not be required; however, an NRC license would most likely be required if dedicated storage is provided by the private sector.

The dedicated storage facility will be both a receiver and shipper, as shown in Figure 4 . Dedicated storage may receive waste from the originator facility, interim storage and treatment facility, and be a shipper to the treatment facility, or disposal facility. DOE and its contractor will need to provide the same transportation operations as interim storage. 


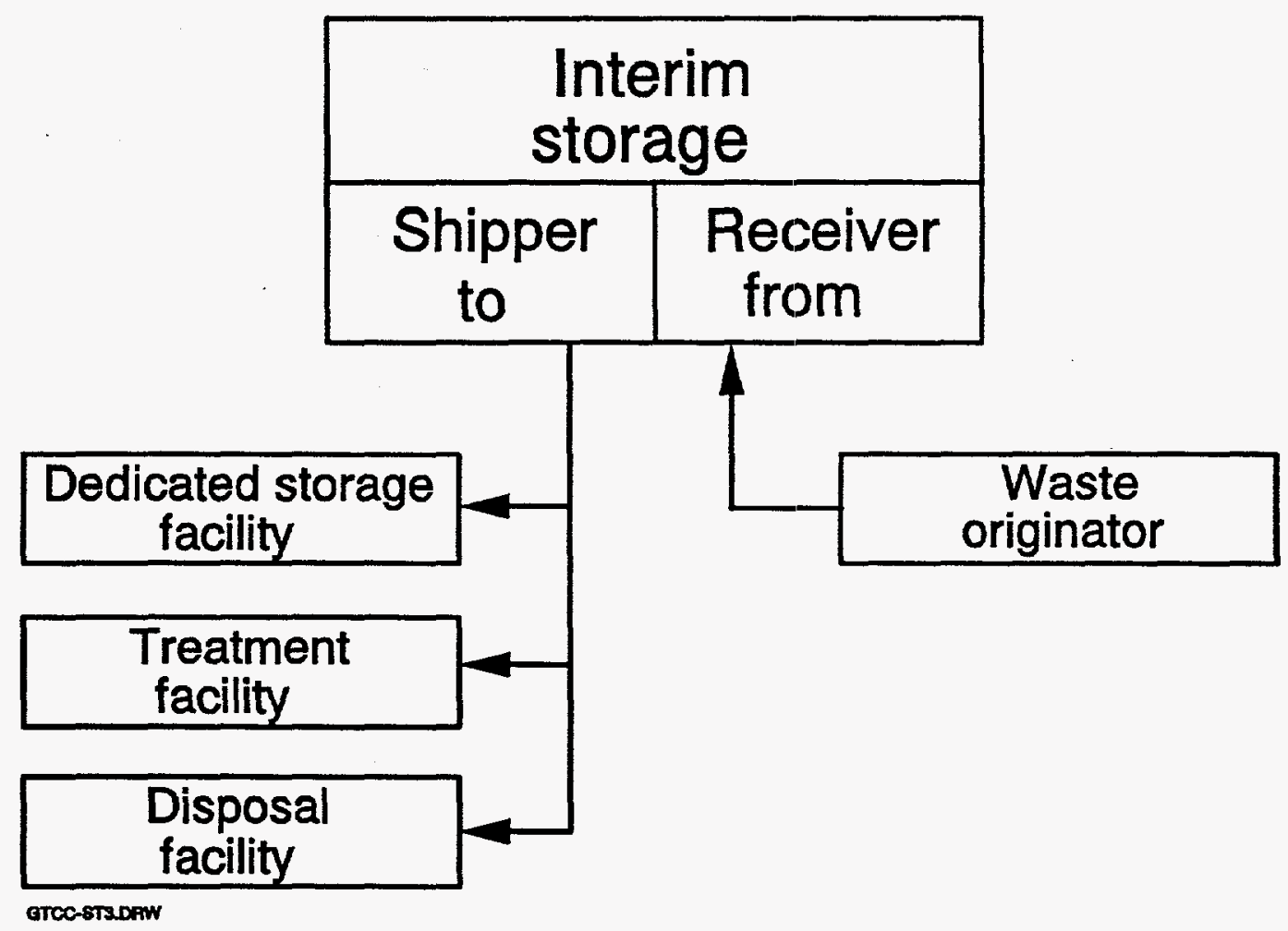

Figure 3. Possible shipper and receiver options for interim storage.

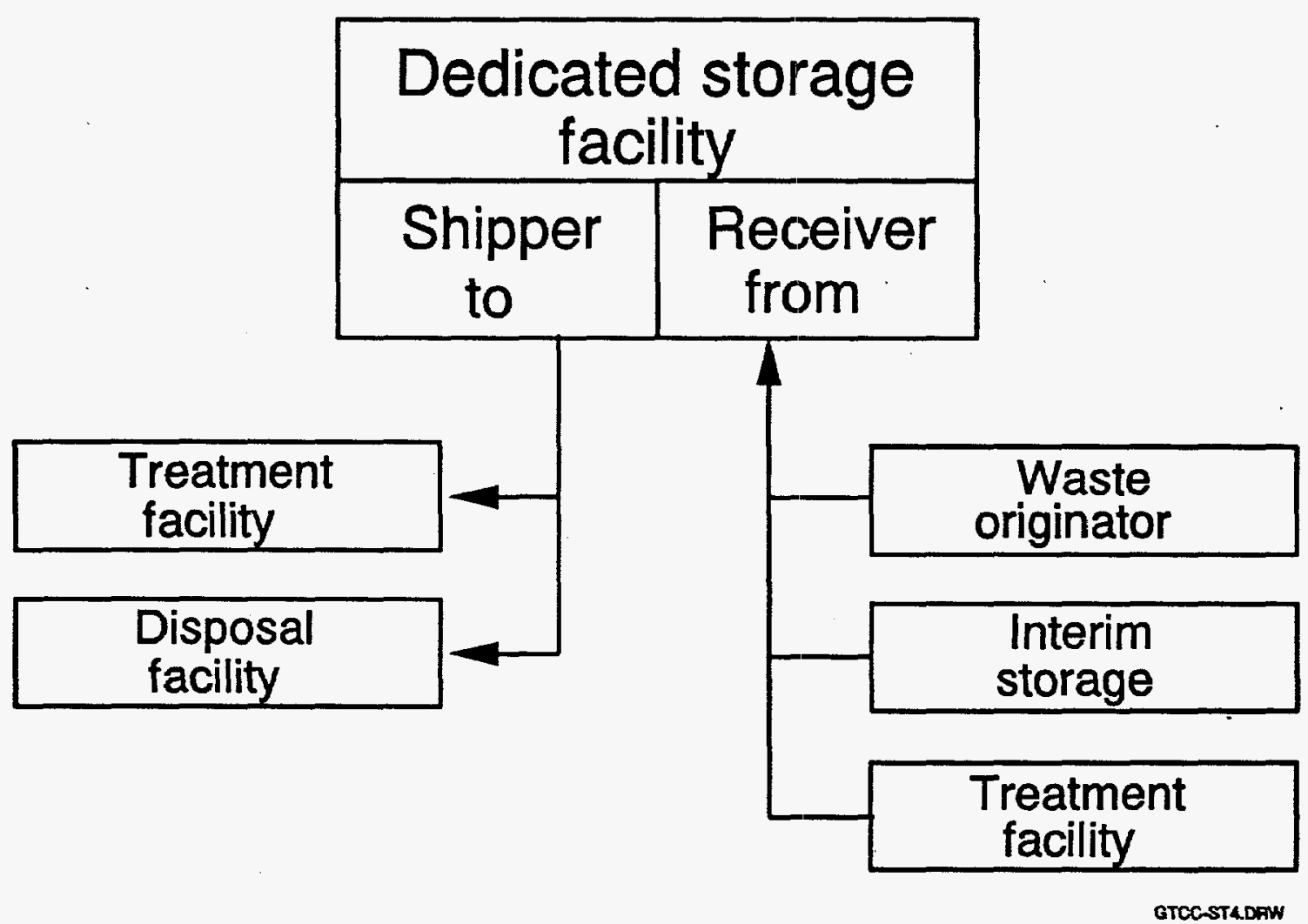

Figure 4. Possible shipper and receiver options for a dedicated storage facility. 


\subsubsection{Treatment}

The GTCC LLW received by the DOE for interim storage or dedicated storage may not be in acceptable form for disposal or may need to be repackaged into other disposal containers for more cost-effective storage or disposal. Present planning requires that wastes needing to be treated be treated prior to being placed in permanent disposal. However, it is conceivable that some of the GTCC LLW will need to be treated prior to shipping to interim or dedicated storage. The DOE strategy for the treatment facility could involve several processes for making the GTCC LLW acceptable for storage or disposal. Treatment processes could include the following:

- Incineration-Incinerating the GTCC LLW may be required or desirable for waste volume reduction and to eliminate some of the other hazardous material constituents.

- Solidification-Stabilizing the waste with concrete, resins, or other materials may be required or desirable to prevent spread of contamination during storage or disposal.

- $\quad$ Sizing-Cutting up large pieces or nonstandard shaped GTCC LLW and placing them into standardized waste containers may be required or desirable to make the waste easier to handle and to conserve on storage and disposal space.

- Repackaging-Removing the GTCC LLW from the waste containers received from the originator facilities may be required or desirable to make the waste easier to handle and to conserve storage and disposal space.

The treatment facility will be both a receiver and shipper, as shown in Figure 5 . The treatment facility may receive waste from the originator facility, interim storage, and dedicated storage facility, and be a shipper to the dedicated storage or disposal facility. DOE and its contractor will need to provide the same transportation operations as described for interim storage.

\subsubsection{Disposal}

The disposal facility will provide final disposal of the GTCC LLW as required by Section 3(b) of the Low-Level Radioactive Wasty Policy Amendments Act of 1985, Public Law 99-240. It is anticipated that disposal will be available by 2010 . This facility is required by law to be licensed by the NRC.

The disposal facility will be a receiver, as-shown in Figure 6. The disposal facility may receive waste from the originator facility, interim storage treatment facility, and dedicated storage facility. DOE and its contractor will need to develop waste acceptance criteria, verify that the originator is satisfying those criteria, and accept and receive the waste in accordance with applicable regulations. 


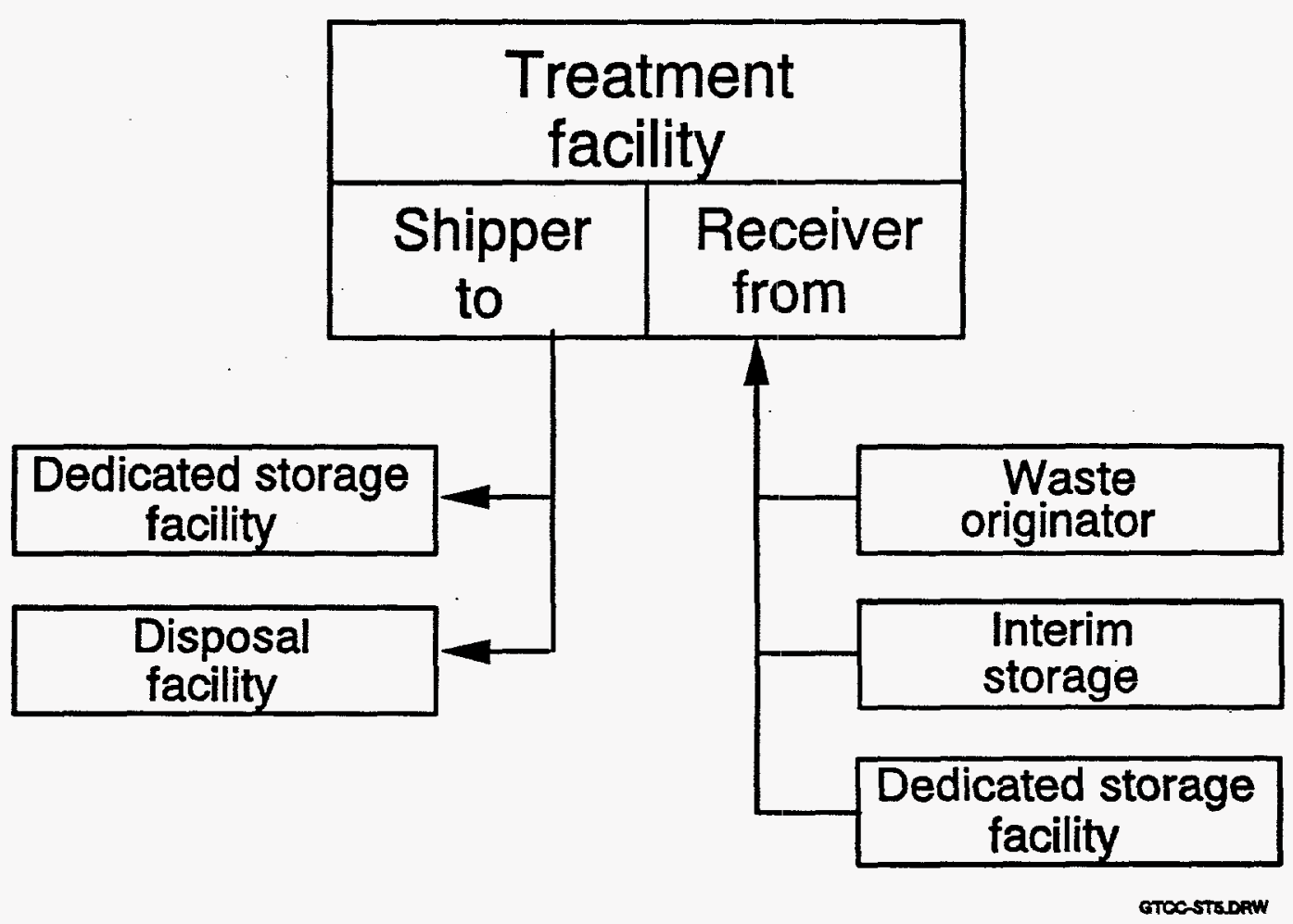

Figure 5. Possible shipper and receiver options for a treatment facility.

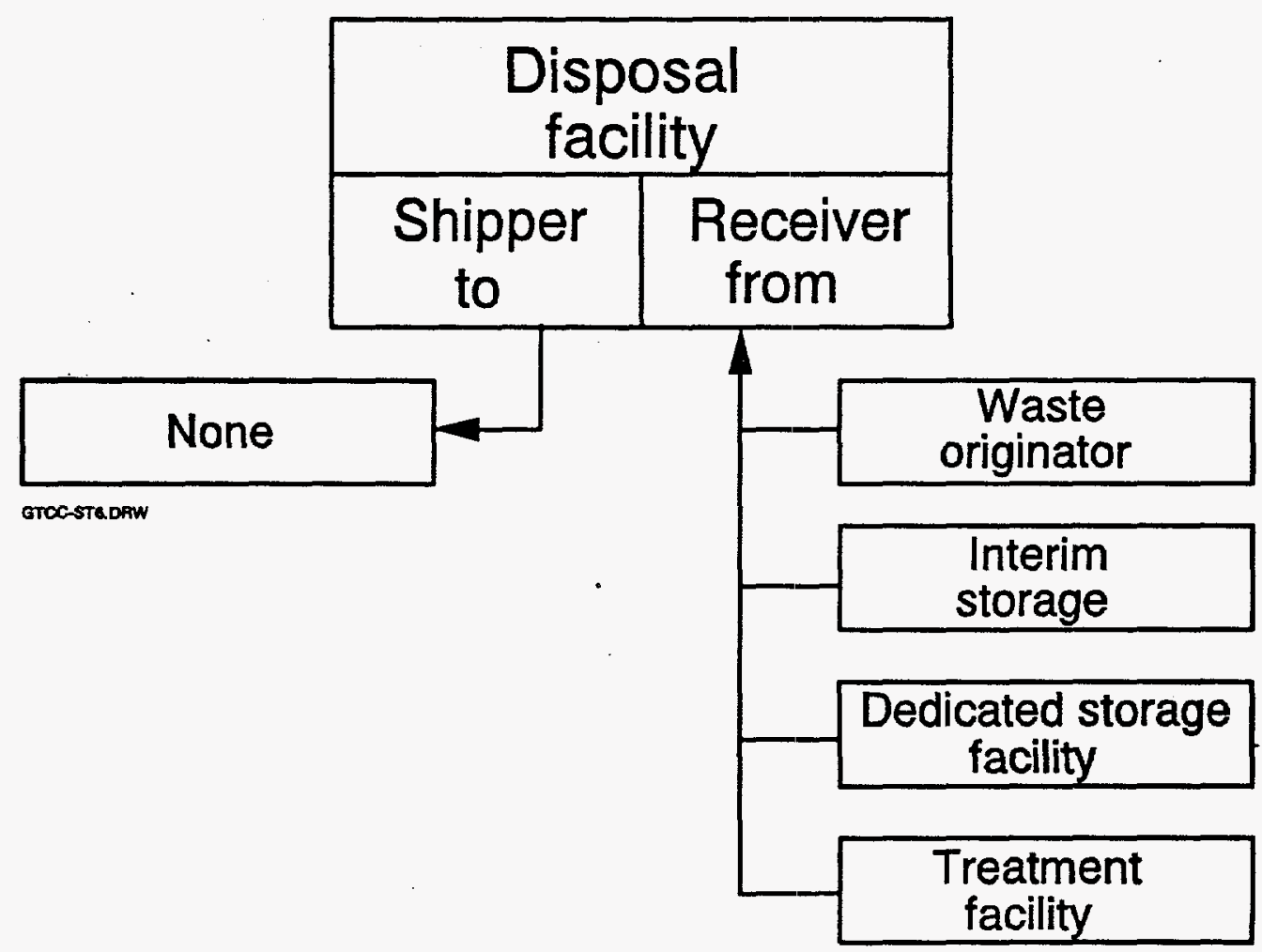

Figure 6. Possible shipper and receiver options for a disposal facility. 


\section{SYSTEM SAFETY AND RISK ANALYSIS}

The NRC and the Interstate Commerce Commission (ICC) have prepared generic environmental impact statements (EISs) for transporting radioactive materials. They are (a) Final Environmental Statement on the Transportation of Radioactive Material by Air and Other Modes, NUREG-0170, NRC, 1977; and (b) Final Environmental Impact Statement, Transportation of Radioactive Materials by Rail, ICC, 1977. These documents identify the potential environmental impacts of shipping radioactive materials and were prepared to fulfill the National Environmental Policy Act (NEPA) requirements to document impacts of major Federal actions. In the past, shippers of spent fuel and other radioactive materials have relied on these documents to fulfill Federal or state NEPA requirements and did not prepare EISs for each campaign. However, this practice is being challenged by state and local governments. State and local governments want analysis of the environmental impacts of transporting specific hazardous materials along a specific route in order to consider the potential risks associated with special circumstances of the particular route. Failure to adequately prepare environmental impact documentation may be challenged in the courts, which could significantly delay the shipping campaign.

\subsection{Requirements}

The DOE GTCC LLW Program is subject to the provisions of NEPA (P.L. 96-196), the Council on Environmental Quality implementing regulations (40 CFR 1500-1508), and DOE . orders (DOE Order 5440.1E). The provisions require appropriate NEPA reviews of programs and projects to support decisionmaking. The NEPA review determines whether proposed actions are categorically excluded or require preparation of an EIS or EA.

\subsection{Responsibilities}

DOE and its contractor is responsible for ensuring that the potential environmental impacts of shipping the GTCC LLW is adequately evaluated and documented in accordance with NEPA requirements. That evaluation and documentation should be in enough detail to address state and local government, tribal, or public concern.

\subsection{Strategy}

Complying with reasonable state and local requests can facilitate relations with parties not directly in the program and establish a more favorable institutional environment. Ideally, DOE's GTCC LLW Program activities (including packaging and transportation) are addressed in a programmatic NEPA document. However, a treatment, storage, or disposal (TSD) facility NEPA document might include transportation issues. If the proposed packaging and transportation activities are not a component of a program or project requiring an EA or EIS, and is routine transportation to an existing TSD, it may qualify for a proposed categorical exclusion (55 FR 46458). An evaluation is needed to determine if an EIS or EA needs to be prepared, or categorical exclusion is appropriate. If it is determined that a categorical exclusion is appropriate, a route-specific plan should be prepared to address route-specific concerns. 


\section{ROUTE}

Routing may be the most important and controversial institutional issue for the GTCC LLW shipping campaign. Citizens and public officials perceive radioactive shipments as hazardous and are concerned about shipment notification, local emergency capability, and road and rail conditions. Those concerns can cause communities to oppose shipment of nuclear materials travelling through their areas. Because of these concerns and the perceived risks of the shipments, many communities have legislated transportation bans. Though these bans may not be withheld in court, they can cause significant delays while being resolved.

Rail shipments pose different routing issues. Many communities oppose rail shipments because the mainline rail routes usually go through heavily populated areas, whereas highway routes usually have beltways that bypass the areas.

Overweight shipments can also be an issue for routing. Overweight shipments require obtaining overweight truck permit from the states, and the states designate the route. Problems are created for carriers by local bans and by states that specify an alternative route in their overweight truck permits that have not been approved by DOT as required by 49 CFR 177.825 . Some states use their overweight permitting authority to impose numerous restrictions and conditions on shipments, which significantly increase the difficulty of shipment scheduling and management. Disputes over routing and permitting issues can result in litigation.

\subsection{Requirements}

DOT requires (49 CFR 177.825) that a carrier transporting radioactive material must be placarded and use a route that minimizes radiological risk. Route determination must be based on information regarding accident rates, transit time, population density and activities, time of day, and day of week during which transportation will occur. The carrier must inform the driver that the driver is transporting a radioactive shipment and must identify a general route to be taken. DOT regulation 49 CFR 397.9 requires that transport of hazardous materials must avoid heavily populated areas, assembled crowds, tunnels, narrow streets, and alleys if possible.

DOT allows and encourages states to designate highway routes that are of equal or greater safety than interstate routes. This allows states to actively participate in route selection. Under 49 CFR 177.825 , the state route selection must include a comparative routing analysis that considers radiological risk, local considerations, and continuity of routes between jurisdictions. The states are required to submit that information to DOT by written notice for DOT approval. There have been cases in which states have responded to local concerns by suggesting highway routing alternatives that detour shipments around population centers in favor of less densely populated areas. Although this strategy may resolve conflicts in one area, it creates disputes in other communities and states. Failure to get DOT approval for the alternate route causes the carrier to be out of compliance with DOT Regulations.

Transporting highway-route-controlled quantities of radioactive material, as defined in 49 CFR 173.403(1), requires the use of preferred routes [interstate system highways or a state routing agency-designated route (49 CFR 171.8)]. Highway-route-controlled quantity shipments 
must have a written route plan as defined in 49 CFR $177.825(\mathrm{c})$. The route plan must contain (a) origin and destination points, the route, all planned stops, and estimated departure and arrival times, and (b) telephone numbers to access emergency assistance in each state to be entered.

There are no routing regulations for rail shipments. Typically, fewer routes are available for rail shipments than for highway shipments. Track classification and conditions, carrier operating efficiency, and the number and location of interchanges all play an important role in determining the route for rail shipments.

\subsection{Responsibilities}

The carriers are responsible for selecting routes. Route selection for shipments from the waste originators to the DOE facilities will be the responsibility of the waste originators and their carrier. Selection of routes between the DOE facilities will be the responsibility of DOE and its contractor and their carrier. It is conceivable that DOE may be required to be part of the route selection between the waste originator and DOE facilities where there is a large number of shipments from numerous originators, originating in the same general area using the same route.

\subsection{Strategy}

The decision whether to use truck or railcar cannot be made at this time. It is reasonable to assume that both modes of transport will be made. Therefore, a strategy should be developed that incorporates both modes of transport. Even though the carrier can designate a route that meets the DOT regulations without preparing a written route plan, unless the shipments are highway-route-controlled, it is recommended that a route plan be prepared. It is easier to prepare a route plan that clearly shows that the routing decisions were based on safety and were not arbitrarily chosen than it is to respond to irate citizens and politicians without such documentation. Having this type of information available can help the shipper gain the confidence of the public and state officials.

The following is brief discussion of the information that should be considered when preparing the plan.

General information-Routing factors must be clearly specified and discussed in terms of maximizing safety (e.g., transit time, highway/track quality, and accident history, etc.). It is important that the proposed routes be independently reviewed and alternatives identified to show the relative risks. Such an independent review provides objective evidence that can lend credibility to routing decisions.

It is important that the shipper develop detailed knowledge of the route(s) in order to identify problems with the route and respond with credibility to local questions when they arise. If areas of concern are expressed by the public, shippers should investigate them before making the shipment. Such measures indicate that local concerns are being taken seriously and responded to accordingly. Paying attention to local concerns and acting to reduce these concerns can be very valuable. 
Highway shipments-Every effort should be made to avoid using oversized shipments. As previously stated, states and local governments can use the permitting process to dictate routes and can delay and complicate the shipments.

Rail shipments-The quality of track, dangerous intersections, and road conditions during winter months are all community issues. It may be valuable to have the Federal Railroad Administration evaluate potential infrastructure problems or potentially dangerous features that are of concern to local officials. 


\section{EMERGENCY PREPAREDNESS AND RESPONSE}

The root of all institutional issues are related to concerns about the safety of the shipments and emergency preparedness and response capabilities. Since state and local governments are responsible for all emergencies in their area, emergency preparedness and response capabilities are critical. Most state and local government officials feel strongly that they should be prenotified and provided with detailed information of hazardous shipments through their areas. They want to ensure that their emergency response personnel are properly prepared and are on alert in the event of an accident. They are required by law to ensure that their emergency responders are properly equipped and trained for the emergency. Issues may arise concerning payment of fees imposed by the states for escorts, inspections, and emergency response staff.

\subsection{Requirements}

As part of the Emergency Management System (EMS), DOE and DOE contractors establish and maintain emergency management programs consisting of plans and procedures for response to operational emergencies involving or affecting DOE facilities. DOE elements and the managers/administrators of DOE- or contractor-operated facilities establish emergency readiness assurance programs, as set forth in DOE Order 5500.10.

DOT emergency response information and telephone number requirements are found in 49 CFR 172, Subpart G, Emergency Response Requirements, 172.600 through 172.604.

EPA requirements are found in 40 CFR 265.50, Subpart D, Contingency Plan and Emergency Procedures. Subpart D defines content, copies, amendments, emergency coordinator, and procedures for the contingency plan.

DOE Order 5500.3A states that, where possible, interrelationships with Federal, state, tribal, and local organizations must be prearranged and documented in formal plans, agreements, understandings, and other prearrangements for mutual assistance. These documents detail the emergency measures to be provided by non-DOE entities. State, tribal, and local governments should be encouraged to prepare their own response plans where the emergency planning zone extends beyond DOE boundaries. If state, tribal, and local governments refuse to participate, DOE should include probable state and local response activities in DOE plans.

\subsection{Responsibilities}

The overall responsibility for responding to any type of transportation emergency belongs to the state and local governments where it occurs. State and local governments have police, fire fighter, medical, and emergency management capabilities for responding to emergencies. In the event of a major emergency, the state can request assistance from several Federal agencies to provide expertise and specialized equipment. The commercial sector also has capabilities available to assist in the event of an emergency.

DOE has an extensive emergency response training program that may be available to the GTCC LLW Program. To supplement that training, the Federal Emergency Management Agency 
(FEMA) and DOT have seminars specifically for shipping campaigns that can be given to local officials. These seminars can be conducted for local governments both at the initiation of shippers and at the request of local governments. These seminars can be held for specific communities as well as for groups of local officials. Experience with other shipping campaigns has shown that seminars have been successful in communicating the relative risks of various types of shipments and in establishing more informed first responders. Training seminars should not necessarily be limited to police and fire personnel. Elected local officials who are called upon to respond to citizen concerns would also benefit.

\subsection{Strategy}

Emergency response and preparedness for the GTCC LLW shipments should be integrated with other DOE programs to avoid redundance. Emergency response plans should be written for those areas not covered by existing plans. As a minimum, a plan should be written that ties the GTCC LLW shipments into emergency response planning for other DOE shipping campaigns. The following are examples of plans that should be considered.

- Emergency plan (EP). The EP identifies emergency response, inspection, and enforcement issues, and provides a foundation for issue discussion and resolution processes that prove instrumental in developing a strategy document. These include

- Defining roles and responsibilities

- Defining potential emergency situations

- Defining first responder actions

- Developing system of inspections and a set of inspection criteria

- Determining the definition and eligibility for assistance

- Assesșing potential funding and assistance mechanisms

- Determining training needs by assessing existing training programs, certification or standards process, timing of training, strategy for training assistance to state, tribal, and local governments

- RCRA contingency plan

- Emergency public affairs plan. 


\section{SAFEGUARDS AND SECURITY}

Safeguards and security regulations have been developed to prevent specific nuclear materials (SNM) from being diverted for nonauthorized purposes. Of the four major GTCC LLW waste streams (i.e., activated metals, sealed sources, dry contaminated solids, and processed waste), three are potential sources of accountable nuclear materials. Sealed sources, e.g., gamma gauges, $\mathrm{x}$-ray devices, florescent, well logging, moisture gauges, smoke detectors, and pacemakers all contain amounts of accountable material that may or may not require reporting, depending on the total amount of material being disposed and the requirements of the licensee or contractor. Dry contaminated solids and processed waste may also contain accountable material. Facilities that handle accountable nuclear materials as part of their operations may capture accountable materials in ventilation or liquid purification filters, or be deposited in hardware, i.e., valves, pumps, etc. This material must be accurately recorded to maintain balance and the facilities accountable.

\subsection{Requirements}

The requirements for reporting transfer of nuclear material are stated in NUREG/BR-0006, Revision 3, Instructions for Completing Nuclear Material Transaction Reports and Concise Note Forms. NRC and DOE jointly use the Nuclear Materials Management and Safeguards System (NMMSS). Common reporting form, DOE/NRC Form 741, Nuclear Material Transaction Report, is used to record nuclear material data to meet the reporting requirements of both NRC and DOE.

NRC identifies two types of nuclear material that fall within the safeguards and security requirements. The two categories are (a) source materials (depleted uranium, natural uranium, or thorium) and (b) SNM (U-233, U-235, or plutonium).

The DOE reporting requirements for DOE-owned (leased, loan, contract) materials are covered in the DOE 5630 Order series. Specifically, DOE requires that all nuclear materials be controlled and accounted for as required by the orders. DOE identifies, in DOE Order 5633.3, three types of nuclear materials: source, SNM, and other nuclear materials. Table 2 lists the nuclear materials and reportable quantities for DOE.

\subsection{Responsibilities}

The NRC licensees are responsible for maintaining a record of accountable materials. The $\mathrm{NRC}$ requires that any inventory adjustment involving $1 \mathrm{~kg}$ or more of source material or $1 \mathrm{~g}$ or more of SNM be reported, using DOE/NRC Form 741. Reports are also required whenever nuclear material in the above types and amounts are transferred to or from nuclear waste sites (i.e., if the shipper or receiver report identification symbol begins with the letter $V$ ). The issue of accounting for abandoned sources needs to be addressed by the NRC.

The DOE or its contractors are maintaining accountability of accountable materials identified in Table 2. Submission of DOE/NRC Form 741 is normally required as a matter of contract or lease administration for all DOE-owned nuclear material transferred, regardless of quantity. 
Table 2. Quantities of nuclear materials above which are reportable to the DOE. (DOE Order 5633.3, "Control and Accountability of Nuclear Materials," February 3, 1988)

\begin{tabular}{lcccl}
\hline \multicolumn{1}{c}{ Material } & $\begin{array}{c}\text { Other } \\
\text { nuclear } \\
\text { materials }\end{array}$ & SNM & Source & $\begin{array}{c}\text { Reportable } \\
\text { quantities }\end{array}$ \\
\hline Depleted uranium & - & - & $X$ & Kilogram \\
Enriched uranium & - & $X$ & - & Gram \\
Plutonium-242 & - & $X$ & - & Gram \\
Plutonium-241 & $\mathrm{X}$ & - & - & Gram \\
Americium-241 & $\mathrm{X}$ & - & - & Gram \\
Americium-243 & $\mathrm{X}$ & - & - & Gram \\
Curium & $\mathrm{X}$ & - & - & Gram \\
Berkelium & $\mathrm{X}$ & - & - & Microgram \\
Californium-252 & $\mathrm{X}$ & - & - & Microgram \\
Plutonium 239-241 & - & $\mathrm{X}$ & - & Gram \\
Lithium-6 & $\mathrm{X}$ & - & - & Kilogram \\
Uranium-233 & - & $\mathrm{X}$ & - & Gram \\
Normal uranium & - & - & $\mathrm{X}$ & Kilogram \\
Neptunium-237 & $\mathrm{X}$ & - & - & Gram \\
Plutonium-238 & - & $\mathrm{X}$ & - & Gram/tenth \\
Deuterium & $\mathrm{X}$ & - & - & Kilogram/tenth \\
Tritium & $\mathrm{X}$ & - & - & Gram/hundredth \\
Thorium & - & - & $\mathrm{X}$ & Kilogram \\
& & & & \\
\hline
\end{tabular}

\subsection{Strategy}

DOE needs to work out agreements with the NRC for resolving the following issues: (a) accounting for sources abandoned by NRC licensees, (b) resolving differences between the type and quantity of accountable materials that should be reported, and (c) the originators declaring the material as waste and formally delete it from the records prior to transport to any of the DOE facilities. 


\section{STRATEGY SUMMARY}

The strategy for preparing for and making a successful GTCC LLW shipping campaign has been identified throughout this report. As the details of the program become better defined, the strategy will be revisited to ensure that proposed steps are still applicable. As has been stated in this report, institutional issues will provide the most challenging issues to the shipping campaign. The Institutional Plan in Part II identifies actions needed to minimize the impact from those institutional issues. A summary of the strategy is as follows:

- Transportation Packages

- The Waste Originator is responsible for providing a waste container and shipping cask for shipments to the DOE facilities.

- $\quad$ Avoid using DOE-certified casks to make the shipments.

- For shipments from the DOE facilities to other DOE facilities, DOE and its contractor will be responsible for providing waste containers, if different than the ones used to receive the waste, and shipping packages.

- Clearly identify the type and quantity of radionuclides, activity levels, total amount, and sizes of the waste so that the appropriate type of packaging, i.e., Type A, Type B, fissile, and/or double containment can be determined.

- Develop waste acceptance criteria for the DOE facilities.

- Identify the interface requirements between the package and facilities.

- Evaluate the tradeoffs involved in modes of transportation, i.e., railroad versus highway, and regular shipments versus oversized shipments.

- Prepare a cost-benefit analysis for waste containers and shipping packaging to determine buy, lease, or develop new packaging(s) specifically for GTCC LLW.

- Transportation Operations

- The strategy of DOE and it's contractor should be to minimize involvement in preparing and shipping waste from the waste originator to the DOE facility.

- Prepare a plan that integrates all phases of the transportation activities. Planning should include shipment tracking in transit and communication between transport vehicle and traffic management; security; emergency notifications; routing; notifications; driver training and qualifications; vehicle maintenance and inspection surveillance by state and local governments and Native American tribes; inspection and recertification of transport packaging, worker hazardous communications, and protection; loading and unloading procedures; and a quality assurance plan for the transport and receipt of waste. 
- $\quad$ System Safety and Risk Analysis

- Complying with reasonable state and local requests can facilitate relations with parties not directly in the program and establish a more favorable institutional environment.

- $\quad$ Prepare a route-specific assessment unless a specific EA or EIS, if required.

- Route

- $\quad$ Prepare a route plan even if not required. Clearly specify routing factors (e.g., transit time, highway/track quality, and accident history). Have the plan independently reviewed and verified.

- The shipper should develop detailed knowledge of the route(s), identify problems, inspect areas of concern, and be responsive to local concerns.

- $\quad$ Avoid using oversized shipments, if possible.

- For rail shipments, investigate quality of track, dangerous intersections, and road conditions during winter months because all are community issues. Consider having the Federal Railroad Administration evaluate potential infrastructure problems or potentially dangerous features that are of concern to local officials.

- Emergency Preparedness and Response

- Integrate emergency response with other DOE programs to avoid redundant planning. Emergency response plans should be written for those areas not covered by existing plans. As a minimum, a plan should be written that ties the GTCC LLW shipments into emergency response planning for other DOE shipping campaigns.

- Formally document plans, agreements, understandings, and other prearrangements for mutual assistance, and where possible, interrelationships with Federal, state, tribal, and local organizations as required by DOE Order 5500.3A. If state, tribal, and local governments refuse to participate, DOE should include probable state and local response activities in DOE plans.

- Prepare an emergency plan (EP) that identifies emergency response, inspection, and enforcement issues, and provides a foundation for issue discussion and resolution processes that prove instrumental in developing a strategy document.

- Prepare a RCRA contingency plan.

- Prepare an emergency public affairs plan. 
- Safeguards and Security

DOE needs to work out agreements with the NRC for resolving the following issues: (a) accounting for sources abandoned by NRC licensees, (b) resolving differences between the type and quantity of accountable materials that should be reported, and (c) the originators declaring the material as waste and formally delete it from the records prior to transport any of the DOE facilities. 


\section{REFERENCES}

1. U.S. Department of Energy, Shipment of Radioactive Materials by the U.S. Department of Energy, DOE/DP-0030, UC-71.

2. R. A. Hulse, Greater-Than-Class C Low-Level Radioactive Waste Characterization: Estimated Volumes, Radionuclide Activities, and Other Characteristics, DOE/LLW-114, August 1991.

3. M. J. Tyacke, R. C. Schmitt, Greater-Than-Class C Low-Level Radioactive Waste Transportation Regulations and Requirements Study, DOE/LLW-178, July 1993.

4. Office of Transportation Systems and Planning, Battelle Memorial Institute, Analysis of Institutional Issues and Lessons Learned from Recent Spent Nuclear Fuel Shipping Campaigns (1983-1987), BMI/OTSP-03, May 1988.

5. M. J. Tyacke, Greater-Than-Class C Low-Level Radioactive Waste Shipping Package/Container Identification and Requirements Study, DOE/LLW-184, Draft, July 1993.

6. U. S. Department of Energy, U.S. Department of Energy Headquarters Transportation Roadmap, M92-GT-0709-12, September 1992.

7. American Trucking Association, Federal Motor Carrier, Safety Regulations, Parts 383,390-397, 399 U.S. Department of Transportation Federal Highway Administration.

8. Department of Transportation, 1990 Emergency Response Guidebook, DOT P 5800.5.

9. R. A. Hulse, Greater-Than-Class C Low-Level Radioactive Waste Characterization: Estimated Volumes, Radionuclide Activities, and Other Characteristics, DOE/LLW-114, August 1991. 


\section{Part II}

\section{Institutional Plan for Greater-Than-Class C Low-Level Radioactive Waste Packaging and Transportation}

\section{INTRODUCTION}

Section 3(b) of the Low-Level Radioactive Waste Policy Amendments Act of 1985, Public Law 99-240, assigns the Federal Government responsibility for disposal of Greater-Than-Class C low-level radioactive waste (GTCC LLW). Disposal in a facility licensed by the U.S. Nuclear Regulatory Commission (NRC) is required for GTCC LLW generated by operators with NRC or agreement states licenses. Related provisions of the Act assign the U.S. Department of Energy (DOE) as the Federal agency responsible for implementing the GTCC LLW program. The current (1993) baseline strategy (Reference 1) identifies three major tasks:

- Interim storage

- Dedicated storage

- Disposal.

Reference 1 and Part I of this report provide information and strategy on these tasks to the extent they are presently defined. However, this strategy will be reexamined during FY-94. Associated with each of these tasks are packaging and transportation ${ }^{2}$ activities. Reference 2 also discusses elements of the packaging and transportation activities. This report presents an Institutional Plan for packaging and transport of GTCC LLW. The plan is a further development of one element, Institutional Issues, from Reference 2. For the purpose of definition, institutional issues and the Institutional Plan is identified to encompass the broad range of public involvement that can develop as a result of packaging and transport actions accompanying GTCC LLW task activities.

Assumptions required to proceed with the planning effort are presented in Section 2. Section 3 discusses the source of requirements for packaging and transportation activities. Section 4 provides the bulk of the planning effort and recommends actions to be taken in implementing the plan.

a. Transportation and shipment (ship, shipping, etc.) are used interchangeably in this document. 


\section{ASSUMPTIONS}

In lieu of final decisions for the GTCC LLW programmatic effort, several assumptions are made in order to formulate meaningful institutional planning. These assumptions are as follows:

a. Interim storage, dedicated storage, or both, will be established for accumulating and treating GTCC LLW.

b. The interim or dedicated storage facilities will be located either at Federal facilities or at private sector facilities through DOE contractual arrangement.

c. Disposition of GTCC LLW, either as received from generators or following treatment and repackaging, will be at a geologic repository.

d. Packaging will be performed by the generator and will meet DOE acceptance criteria.

e. Transport from the generators to a GTCC LLW facility (interim storage, dedicated storage, or disposal) will be performed by the generators in compliance with U.S.

Department of Transportation Regulations (49 CFR 171-399). A possible exception would be abandoned waste that might require recovery by DOE.

f. Transport of GTCC LLW from facility to facility or to disposition will be performed by DOE or contractors and will be characterized as frequent or as a shipment campaign.

g. Environmental documentation will be completed and approved as required for any GTCC LLW facility prior to initiation of any GTCC LLW transportation action to the facility. 


\section{REQUIREMENTS}

Requirements delineating preparation of an institution plan for transportation and packaging activities are not directly found in DOE orders. On the other hand, institutional issues in a "global sense" have been an increasingly difficult problem for DOE operations in recent years. Several DOE orders address requirements for elements of operations that collectively contribute to overall needs in good institutional planning:

a. DOE 4700.1, Project Management System. This DOE order identifies the requirements for the project management planning and plans.

b. DOE 5500.4A, Public Affairs Policy and Planning Requirements for Emergencies. This DOE order establishes requirements for DOE public affairs actions for emergency situations and provide guidelines for each departmental organization or facility to develop a public information plan that will ensure that necessary public affairs actions are planned, coordinated, and taken as an integral part of the total emergency response effort.

c. DOE 1540.1A, Materials Transportation and Traffic Management. This DOE order establishes DOE policies and procedures for management of materials transportation activities, including traffic management.

d. DOE 5400.5, Radiation Protection of the Public and the Environment. This DOE order establishes standards and requirements for operations of DOE and DOE contractors with respect to protection of members of the public and the environment against undue risk from radiation.

e. DOE 5440.1E, National Environmental Policy Act Compliance Program. This DOE order establishes DOE responsibilities and procedures to implement the National Environmental Policy Act of 1969.

f. DOE 5480.3, Safety Requirements for the Packaging and Transportation of Hazardous Materials, Hazardous Substances, and Hazardous Wastes. This DOE order establishes requirements for the proper packaging and transport of hazardous materials on-site (INEL) and off-site.

g. DOE 5820.2A, Radioactive Waste Management (in revision). This DOE order establishes policies, guidelines, and minimum requirements by which DOE manages its radioactive and mixed waste and contaminated facilities.

h. DOE 1200.1A, Policy and Procedures for Departmental News Media Activities. This DOE order establishes policies and procedures for DOE and its contractors on the preparation and release of unclassified information to the public through the news media and on planning and implementation of activities intended primarily for news media. 
Other sources of hazardous materials transportation regulatory requirements are the Federal regulations pertaining to the transportation of hazardous materials, which include radioactive and fissile materials. The regulations contain provisions for classification, packaging, marking, and labeling of such materials. They are issued by the following agencies and are codified and published in the Code of Federal Regulations.

a. United States Nuclear Regulatory Commission Regulations.

(1) Title 10, Code of Federal Regulations (CFR), Part 71, "Packaging of Radioactive Material for Transport, and Transportation of Radioactive Material Under Certain Conditions," prescribes Federal standards applicable to licensee shippers of nonexempt quantities of radioactive materials.

(2) Title 10 CFR Part 73, "Physical Protection of Plants and Materials," prescribes shipment standards.

b. United States Department of Transportation Regulations. Title 49 CFR Parts 100-199, Subchapters A-C, "Hazardous Materials Regulations," provide requirements applicable to shippers and carriers of hazardous commodities.

c. United States Postal Service Regulations. Publication 52, "Acceptance of Hazardous or Perishable Articles," prescribes applicable postal regulations.

d. United States Environmental Protection Agency. Title 40 CFR, designates the types of hazardous materials regulated.

e. United States Customs Service Rules. Title 19 CFR and Public Law 95-242, "Import/Export of Nuclear Materials."

In addition to the preceding regulations covering the transportation of hazardous materials, there are several transportation acts and regulations that assign responsibilities, establish requirements, and prescribe procedures for transportation in general or in other specific areas. Some of these follow:

a. Interstate Commerce Act. Title 40 U.S.C., authorizes the Interstate Commerce Commission to regulate rates, rules, and practices of carriers engaged in interstate commerce.

b. Hazardous Materials Transportation Act. Title 49 U.S. C. 1801 and following define regulatory and enforcement authority of the Secretary of Transportation to protect the nation against the risks inherent in the transportation of hazardous materials.

A more complete list of sources of regulatory requirements and related reference materials for packaging and transportation can be found in DOE 1540.1A (5.b through 5.e) and in Reference 3. 


\section{INSTITUTIONAL PLAN ELEMENTS AND ACTIONS}

Institutional issues in transport and packaging have been cited in a number of documents. ${ }^{4-8}$ The issues most often identified are

- Route selection and route safety (including local restrictions and bans)

- Cask safety and certification (including challenges to licensing authority and criteria)

- State inspections and escorts and associated state fees (including DOE/State litigation actions)

- Purpose and necessity of shipments (including challenges to legality and authority for shipments)

- Overweight truck permitting issues

- Environmental documentation on compliance with NEPA and assessment of environmental impacts

- Transit near of large cities, including time-of-day transit concerns

- Prenotification and communicating procedures (between shippers and the states or communities)

- Local and Federal emergency response capabilities.

These issues have most often been encountered with transport of spent nuclear fuel (SNF) or high-level waste (HLW). It is not anticipated that all of the GTCC LLW transport activities will generate the same level of public attention. For example, the transport of GTCC LLW from generators (NRC and agreement state licenses) is assumed (Assumptions $d$ and e) to be executed by the licensees in accordance with Federal regulations (certified/licensed packaging and in compliance with DOT requirements). The shipments from any single generator to an interim or dedicated storage facility are expected to be infrequent and, accordingly, should attract little more attention from the public domain, from a transport standpoint, than similar shipments of low-level waste (LLW) from a generator to a LLW disposal site. On the other hand, transport activities from a storage facility to disposal, or some similar activity, having the character of a sizable, frequent, or campaign transport nature could attract considerable attention (such as the proposed activities for the Waste Isolation Pilot Plant in New Mexico).

Regardless of expectations regarding attracting public attention in the GTCC activities, preparation and planning is prudent to alleviate any worst-case public interaction scenario. 


\subsection{Program/Project Plan}

DOE 4700.1 establishes the requirement for preparation of program/project plans for operations in DOE facilities. For the GTCC LLW programmatic activity, operations in the overall sense should include all ancillary operations, e.g., transportation activities. Preparation of such plans can serve a number of functions, including providing a methodology for addressing many of the institutional issues that may arise in pursuing the GTCC LLW programmatic activities. A well-developed programmatic plan can be especially effective in convincing the public or public officials that the activity has been carefully considered and planned.

Institutional Plan Action Item 1-The GTCC LLW programmatic effort should be submitted to detailed program/project planning as soon as decisions for the activity are delineated. A subset of this planning activity should be the preparation of presentation materials such as handouts, brochures, and videos. The presentation should be geared to a laymen audience with a view to be readily understandable by an audience of the general public/public officials. The issues identified above, as they may apply to the various portions of the GTCC LLW activity should be addressed in the plan and in the presentation materials.

\subsection{Public Information Planning and Coordination}

The need for effective shipment planning and close coordination of shipment participants has been emphasized repeatedly in the references. From Reference 4:

"Failure to adequately plan and coordinate shipping activities was identified as a source of problems such as premature release of information about the campaign, presentation of conflicting information or policies to state and local officials and the media, and internal confusion. Recommendations for avoiding these types of problems include early and periodic meetings involving all key shipment participants, designation of a single spokesperson for the program, and careful and ongoing planning and coordination to provide timely information to state and local officials along the route." Reference 8 strongly advocates the importance of a single spokesperson to provide consistent continuity and coordination to the programmatic information being released to the public.

Institutional Plan Action Item 2-The GTCC LLW program should identify a single source of contact to serve as spokesperson to news media, special interest groups, and the public, and to assist with communications with state and local officials. A community relations professional is recommended. This spokesperson should be provided with a complete background concerning technical issues and political sensitivities of the activity. The spokesperson would have access to programmatic technical personnel for resolution of issues germane to the program. The spokesperson would participate in the activities to provide or prepare materials addressing the institutional issues of the program. The spokesperson would maintain records of the public interaction for historical and quality objectives of the program. 


\subsection{Environmental Compliance Documentation}

The need for and importance of adequate environmental documentation cannot be overstated in DOE activities at this time. It is not supposed that the process of GTCC LLW shipments from generators to interim or other storage will require any environmental documentation that departs from that which already exists in the law (shipments in compliance with Federal regulations for which environmental documentation exists). On the other hand, transport campaigns from storage to disposal and the storage facility itself will probably bear special documentation considerations. Environmental documentation in the form of checklists, categorical exclusions based on tiering to larger Environmental Impact Statements (such as a larger facility; i.e., INEL EIS), environmental assessments, or other environmental documentation are expected to be required. Transportation activities to and from GTCC LLW facilities should be incorporated as fully as possible into these environmental documents.

Institutional Plan Action Item 3-The GTCC LLW program should initiate a review of environmental documentation requirements for its programmatic actions at the earliest possible date once decisions on programmatic activities and facilities are final. Transportation should be integrated as one element of the activity if possible. Otherwise, transportation to and from facilities should be evaluated separately. A fully defensible environmental compliance status for transportation is required.

\subsection{Shipment Policy and Procedures}

Previous experience indicates that the intensity of institutional issues during transportation operations can be significantly relieved if transport policy and procedures do not depart for from the norm. As examples, the use of overweight trucks and consequent permitting issues from state-to-state, transport administrative differences between DOE and utilities, and procedural differences between DOE and the NRC can cause confusion at the state and local levels.

Institutional Plan Action 4-The GTCC LLW program should plan for the most "straight forward" transport activities; i.e., use of the most prevalent shipping procedures and avoidance of overweight cask systems.

\subsection{State, Local, and Tribal Interaction}

As stated in Reference 4, effective interaction with State and local officials is critical to successful shipping operations; an observation that was also strongly stated in References 5, 6, and 8. From Reference 4:

"Issues of routing, environmental impact documentation, and compliance with state and local requests for inspections, escorts, and payment of State fees arose in a number of campaigns and were not easily resolved. The experience of these campaigns indicates that all routes and modes of transport, especially during long campaigns, are likely to evoke some opposition. Recommendations for addressing local concerns include demonstration of detailed knowledge of the route, willingness to discuss 
routing and other issues with State and local officials along the transportation corridor, effectively communicating information on transportation risks to the concerned public, and responding sensitively to community concerns about safety. The provision of shipment-specific analysis of environmental impacts was not, by itself, found to be effective in reducing local concerns or increasing public confidence in shipment safety. Some of those interviewed felt that shippers should make a genuine effort to cooperate with States and localities interested in providing inspections and escorts and should consider providing information and technical support on emergency training."

Institutional Plan Action Item 5-The GTCC LLW program, through its spokesperson, should initiate communications with all states, the public, tribal constituents, and local communities as requested, along the shipping corridor, from a GTCC LLW facility to the disposition location. The initiation of this communication should occur as early as possible prior to the start of a concentrated (campaign type) transport action.

\subsection{Emergency Response}

Included in DOE 1540.1A, 8C(1)-(3) are discussions of emergency response issues and requirements. DOE maintains a radiological assistance plan (RAP) for responding in case of a radioactive material incident or release in transit, and the Chemical Transportation Emergency Center (CHEMTREC), maintained by the chemical industry, is a clearinghouse for information and assistance on all types of chemical spills, including radioactive. For materials with radioactive properties, the Center activates the DOE regional coordinating office having jurisdiction.

Additionally, all DOE-owned shipments of radioactive and other hazardous material must comply with the DOT requirements for Emergency Response Information as cited in 49 CFR, Subpart 6, Sections 172.600-172.604. There are reporting requirements for hazardous material leakage or radioactive contamination during shipping, as identified in DOE $1540.1 \mathrm{~A} 7 \mathrm{~d}$.

Institutional Plan Action Item 6-Emergency response capabilities for a transport incident should be addressed as early as feasible in the GTCC LLW program plan and reviewed on a regular basis. Capabilities of the Federal Government to respond to a transport emergency, such as contained in DOE 1540.1A, should be included in the plan.

An emergency response plan should be developed. The plan should be integrated with overall program/project planning and/or in a Transport Plan, Item 4.7 below, if a decision to prepare such a transport plan is made.

The GTCC LLW program should also monitor or participate in the various emergency response training exercises and programs ongoing for affected states and communities. 


\subsection{Transport Plans}

DOE 1540.1A identifies that a shipment plan shall be submitted to EM-361 45 days in advance for DOE shipments of highway route controlled quantities of radioactive materials that are of a frequent or campaign character. Typically, a formal Transport Plan is not a requirement for DOE on- or off-site shipments where licensed packages are used in compliance with DOT requirements. But there are exceptions, such as a plan preparation effort for the WIPP shipments. DOE program officials can require a formal Transport Plan if in their judgment the action warrants one.

The use of some form of transport planning, either as a section of the GTCC LLW program/project plan or as a stand-alone document, could have sizeable benefits. Aside from the DOE requirement for a shipment plan, such a planning document could be used with the public, public officials, and the state to ease transport information needs.

Institutional Plan Action Item 7-The GTCC LLW program should prepare a transport plan document, either as a section of the GTCC LLW Program/Project plan or as a stand-alone formal Transport Plan document that could be appended to the overall plan. The decision on the type of plan can be decided by program officials. The plan should be included for use as needed in notifying/explaining the transport action to outside parties such as the state and EM-361. The plan should address all principle elements of interest from a transport standpoint, e.g., packaging, transport modes, emergency response, and routes. 


\section{CONCLUSIONS}

The foregoing discusses institutional issues and institutional planning elements. Section 4, summarized in Table 1, taken with the proposed actions cited therein, provides the basis for formulating an Institutional Plan. It is particularly recommended that the planning action be subjected to review on a regular basis as future developments in transportation unfold in the United States.

Table 1. Summary of Institutional Plan action items.

\begin{tabular}{|c|c|c|}
\hline Item & Action & Description \\
\hline 1 & $\begin{array}{l}\text { Program/Project } \\
\text { Plan-presentation } \\
\text { materials }\end{array}$ & $\begin{array}{l}\text { Prepare and submit detailed program/project planning as soon as } \\
\text { decisions for the activity are delineated. A subset of this planning } \\
\text { activity should be the preparation of presentation materials such as } \\
\text { handouts, brochures, and videos. (Section } 4.1 \text { ) }\end{array}$ \\
\hline 2 & $\begin{array}{l}\text { Single-source } \\
\text { contact }\end{array}$ & $\begin{array}{l}\text { Identify a single source of contact to serve as spokesperson to news } \\
\text { media, special interest groups, and the public, and to assist with } \\
\text { communications with State and local officials. (Section } 4.2 \text { ) }\end{array}$ \\
\hline 3 & $\begin{array}{l}\text { Environmental } \\
\text { documentation } \\
\text { review }\end{array}$ & $\begin{array}{l}\text { Initiate a review of environmental documentation requirements for } \\
\text { its programmatic actions at the earliest possible date once decisions } \\
\text { on programmatic activities and facilities are final. (Section } 4.3 \text { ) }\end{array}$ \\
\hline 4 & $\begin{array}{l}\text { Straight forward } \\
\text { transport activities }\end{array}$ & $\begin{array}{l}\text { Plan for the most straight forward transport activities, i.e., use of } \\
\text { the most prevalent shipping procedures and avoidance of } \\
\text { overweight cash systems. (Section } 4.4 \text { ) }\end{array}$ \\
\hline 5 & $\begin{array}{l}\text { State and local } \\
\text { government } \\
\text { communication } \\
\text { program }\end{array}$ & $\begin{array}{l}\text { The Communication Program should (a) through its spokesperson, } \\
\text { initiate communications with all states, the public, tribal } \\
\text { constituents, and local communities as requested along the shipping } \\
\text { corridor from a GTCC LLW facility to the disposition location; (b) } \\
\text { address emergency response capabilities for a transport incident as } \\
\text { early as feasible in the GTCC LLW program plan and reviewed on } \\
\text { a regular basis; and (c) the GTCC LLW program should also } \\
\text { monitor the ongoing revision for the INEL Emergency Public } \\
\text { Affairs Plan from the view of facilities and transportation related } \\
\text { content (or noncontent). (Section } 4.5 \text { ) }\end{array}$ \\
\hline 6 & $\begin{array}{l}\text { Emergency } \\
\text { Response Planning }\end{array}$ & $\begin{array}{l}\text { An emergency response plan should be developed based on a } \\
\text { review of available resources and ongoing federal assistance in } \\
\text { emergency response with effected communities and states if } \\
\text { applicable. }\end{array}$ \\
\hline 7 & Transportation Plan & $\begin{array}{l}\text { Prepare Transport Plan document, either as a section of the } \\
\text { GTCC LLW Program/Project Plan or as a stand-alone formal } \\
\text { Transport Plan. The plan should include packaging, transport } \\
\text { modes, emergency response, routes, etc. (Section } 4.6 \text { ) }\end{array}$ \\
\hline
\end{tabular}




\section{REFERENCES}

1. Greater-Than-Class C Low Level Radioactive Waste Program, 1992 Baseline Strategy, DOE/LLW-172, February 1993.

2. Greater-Than-Class C Low-Level Radioactive Waste Packaging and Transportation Elements Report, DOE/LLW-116, U.S. Department of Energy, October 1991.

3. Greater-Than-Class C Low-Level Radioactive Waste Transportation Regulations and Requirements Study, DOE/LLW-178, U.S. Department of Energy, July 1993:

4. Analysis of Institutional Issues and Lessons Learned from Recent Spent Nuclear Fuel Shipping Campaigns (1983-1987), BMI/OTSP-03, Battelle Memorial Institute, May 1988.

5. TMI-2: Lessons Learned by the U.S. Department of Energy, DOE/ID-10276, U.S. Department of Energy, March 1990.

6. Historical Summary of the Three-Mile Island Unit 2 Core Debris Transportation Campaign, DOE/ID-10400, U.S. Department of Energy, March 1993.

7. Vinginia Power and Department of Energy Spent Fuel Transportation Experience, EGG-2491, EG\&G Idaho Report Prepared for U.S. Department of Energy, December 1986.

8. T. A. Smith, "Community Relations for the Transport of TMI-Z Core Debris," EG\&G-M-88 192, Topical Meeting on the TMI-2 Accident: Materials Behavior and Plant Recovery Technology, Washington D.C. October 31-November 4, 1988. Paper available from American Nuclear Society, Inc., LaGrange Park, IL 60525. 